\title{
Leptachirus, a new soleid fish genus from New Guinea and northern Australia, with descriptions of eight new species
}

\author{
John E. Randall \\ Bishop Museum, 1525 Bernice St., Honolulu, Hawaii 96817-2704, U.S.A.; \\ E-mail: jackr@hawaii.rr.com
}

\begin{abstract}
Leptachirus is described as a new genus of Soleidae for Aseraggodes klunzingeri (Weber) and eight new species from fresh or brackish water habitats in southern New Guinea and northern Australia formerly identified as $A$. klunzingeri. Leptachirus is differentiated from Aseraggodes, all species of which are marine, by its more slender body (depth 2.7-3.55 in SL), the corner of its jaws exposed on the cheek, usually 3 or 4 pelvic rays, shorter pelvic fins, each usually with 3 or 4 rays, and different pattern of its cephalic lateralis sensory system. The type species, $L$. alleni, is from the Bintung River, New Guinea; L. bensbach, L. kikori, and L. lorentz are named for the rivers in New Guinea in which they were collected; $L$. robertsi is from the Fly River in Papua New Guinea; $L$. darwinensis, very similar to $L$. bensbach, from the East and South Alligator Rivers and the Adelaide River of the Northern Territory of Australia; L. polylepis, with a high lateral-line scale count of 103-111, from the East, West, and South Alligator Rivers and the Mary River; and L. triramus from the Victoria River of Northern Territory and the nearby Ord River of Western Australia. The last species is the most divergent, having three instead of two branches of the lateral line on the ocular side of the head, and the pelvic fin of that side attached to the genital papilla. The holotype of L. klunzingeri Weber, described from one specimen collected in the mouth of the Merauke River, New Guinea, has been lost. Weber's illustration shows a fish with a deeper body and broader interorbital space than the other eight species. Additional species of Leptachirus might be expected from other rivers of New Guinea and northern Australia are better collected.
\end{abstract}

\section{INTRODUCTION}

Weber (1908) described Pardachirus klunzingeri as a new species of sole from one $105 \mathrm{~mm}$ specimen collected from brackish water at the mouth of the Merauke River on the south coast of New Guinea, in what is now the Indonesian province of Papua. Unfortunately, the specimen is not extant, but Weber provided a very good drawing (reproduced as Figure 5).

The Zoologisch Museum of Amsterdam loaned eight specimens (ZMA 109.399, 54.5-81.0 mm SL) from freshwater in the Lorentz River of southern New Guinea that were identified as Aseraggodes klunzingeri by Weber (1913). The mouth of this river is $450 \mathrm{~km}$ to the northwest of the Merauke River along a low marshy coastline, so the specimens might be expected to be klunzingeri. However, the Lorentz River specimens are a different species.

Recent studies of the genus Aseraggodes by Randall and Meléndez (1987), Randall (1996, 2002, 2005), Randall and Bartsch (2005), Randall and Gon (2005), Randall and Senou (2007), Randall and Bartsch (in press) and Randall and Desoutter (in press) have raised the total number of species of the genus to 47 , making it the largest of the Soleidae, all from marine habitats.

After Pardachirus klunzingeri was reclassified in the genus Aseraggodes by Weber (1913), specimens identified as klunzingeri have been consistently placed in this genus. These specimens are all from fresh or brackish water habitats, have a more slender body, the posterior end of the jaws exposed on the cheek, usually 3 or 4 pelvic rays, shorter pelvic fins, and a cephalic lateralis sensory system on the blind side characterized by numerous temporal commissures of papillae and cirri linking the dorsal main branch of the lateral line with the cephalodorsal line along the base of the dorsal fin. They are reclassified here in a new genus.

Examination of specimens identified as Aseraggodes klunzingeri from rivers on the south coast of New Guinea, including Weber's specimens from the Lorentz River, and northern Australia has revealed eight new species in a new genus, which are described in the present paper.

Specimens of the new genus are lacking from many rivers and estuarine areas of New Guinea 
(including none from the north coast) and northern Australia. There is an obvious need for more collecting and systematic research on the genus. It is recommended that tissue samples be taken of new material so that molecular analyses are possible.

\section{MATERIALS AND METHODS}

Type specimens of the new species are variously deposited in the Natural History Museum, London (BMNH); Bernice P. Bishop Museum, Honolulu (BPBM); Museums and Art Galleries of the Northern Territory, Darwin (NTM); Queensland Museum, Brisbane (QM); Western Australian Museum, Perth (WAM); United States National Museum of Natural History, Washington, D.C. (USNM); Zoologisch Museum, Amsterdam (ZMA); and the Museum für Naturkunde, Humboldt Universität, Berlin (ZMB).

Specimen lengths in lists of material examined are standard length (SL), measured horizontally from the front of the upper lip to the base of the caudal fin (end of hypural plate). Body depth is the maximum distance between the bases of the dorsal and anal fins; body width is the maximum thickness midlaterally between the ocular and blind surfaces (excluding the abdomen). Head length (HL) is measured from the front of the upper lip to a vertical at the fleshy posterior end of the operculum. Eye diameter is the greatest diameter of the lower eyeball (the dark part of the eye, not the fleshy cutaneous part). Preorbital length is the distance from the front edge of the upper eye directly forward to the anterior edge of the dorsal fin (but not to tips of cirri). Snout length is taken from the front of the upper lip to the nearest edge of the upper eye. Interorbital width is the vertical distance between horizontal lines at the ventral edge of the upper eye and the dorsal edge of the lower eye. Upper-jaw length is measured on the blind side from the front of the upper lip to the rear edge of the maxilla (difficult to determine the posterior end of the maxilla on the ocular side). Caudal-peduncle depth is the least depth, and caudal-peduncle length the horizontal distance between verticals at the rear base of the anal fin and the base of the lowermost caudal ray. Fin rays are referred to simply as rays. Lengths of rays of the median fins are measured from the base of the ray (not where it emerges from the basal scaly sheath) in a straight line to the tip. Pelvic-fin length is taken from the base of the first ray to the tip of the longest ray.

Tables 1 to 4 provide counts of dorsal rays, anal rays, lateral-line scales, and vertebrae, respectively. Tables 5-11 are the proportional measurements of the new species as percentages of the standard length. Measurements as ratios related to standard length, body depth, head length, or eye diameter (dark part of the eye) in the text are rounded to the nearest 0.05 . Data in parentheses in the descriptions refer to paratypes.

Lateral-line scales were counted on the ocular side from the base of the caudal fin to the point of branching of the lateral line on the head, including several scales anterior to the upper end of the gill opening. Scale counts above and below the lateral line are the highest obtained on the ocular side in an oblique row between the lateral line and the outer edge of the scaly sheath at the base of the dorsal and anal fins, respectively.

Ochiai (1963: Text-fig. 1 A) is followed in the terminology of the cephalic lateralis system. His count of dorsal pterygiophores anterior to the fourth neural spine (third spine of Ochiai who overlooked the neural spine of the tiny first vertebra) is also recorded for the species here.

Cyanine Blue 5R (Acid Blue 115) was used to aid in the detection of sensory papillae, fine cirri, and the cteni of scales (Saruwatari et al., 1997).

\section{Family Soleidae}

\section{Leptachirus gen. nov.}

\section{Type species}

Aseraggodes alleni sp. nov.

\section{Diagnosis}

Dorsal rays 65-78; anal rays 50-59; dorsal and anal rays branched except for a variable number anteriorly; caudal rays typically 18 (usually 14-16 branched in adults, and most of these doublebranched); no pectoral fins; pelvic rays 3 or 4 (rarely 5); lateral-line scales 73-111 (including those extending horizontally onto head to the point of branching); lateral line continuing into caudal fin along dorsal edge of tenth ray about three-fourths distance to fin margin; no gill rakers; abdominal vertebrae 9 or 10 (including the first very small vertebra, not counted by some authors); total vertebrae 36-42; first two dorsal pterygiophores joined to a thicker bone termed the erisma and counted as one pterygiophore (branched distally to support the first two dorsal rays); 7-11 dorsal pterygiophores anterior to fourth neural spine; body elongate, the depth 2.7 to 3.55 in SL, and very compressed; eyes on right side, elevated, separated by a narrow scaled space; upper eye in advance of lower eye; caudal peduncle usually absent (if present, extremely short); scales small and ctenoid; a straight lateral line midlaterally on both sides, forming two or three branches on ocular side of head, the ventral branch following posterior margin of preopercle beneath; a thin cephalodorsal sensory line on ocular side from front of snout, passing 
posteriorly below base of dorsal fin, and indistinctly onto anterior body (difficult to detect on some specimens); lateral line extending with pores into caudal fin along dorsal edge of tenth ray (counting from dorsal side of fin) about three-fourths distance to posterior fin margin; lateral line on blind side dividing to two rows of sensory papillae at level of posterior edge of preopercle, diverging as they continue to front of snout; cephalodorsal line on blind side from front of snout, along base of dorsal fin, becoming indistinct on body; zone between dorsal branch of lateral line on head and cephalodorsal branch crossed by 10-20 temporal commissures of sensory papillae and cirri; blind side of head with a broad mixed zone of papillae and cirri ventrally, with a preopercular sensory line extending to lateral line at branching point; a mandibulo-opercular line submarginally on ventral edge of head, curving to upper end of gill opening; transverse sensory branches linking ventral part of mandibulo-opercular and preopercular lines; a sensory line connecting preopercular branch to corner of mouth; no prominent pore at base of dorsal and anal rays; gill membranes united, free from isthmus, the lower part of head scaled over from ocular to blind side; mouth ventral and small; jaws strongly curved; posterior corner of jaws visible externally on ocular side; a curved band of villiform teeth posteriorly on blind side of jaws, broadest centrally (but enveloped in fleshy tissue and difficult to detect); two nostrils on each side, the anterior of ocular side tubular, in slight depression, not longer than its base, and at most slightly tapered; edge of basal depression of anterior nostril rimmed dorsally by arc of small papillae in single row; posterior nostril of ocular side a slit in labial groove before lower eye; dorsal fin originating anteriorly on snout, the first ray not prolonged; caudal fin rounded, not broadly connected by membrane to dorsal and anal fins; pelvic fins on ventral edge of body, close together anteriorly, their origins adjacent or the ocular-side slightly anterior; pelvic fins short, not reaching posterior to base of second anal ray; anus in fleshy protuberance anterior to first anal ray; genital papilla small, dorsoposterior to anus; sciatic part of urohyal forming an angle of about $75-105^{\circ}$ to horizontal main part of bone, the inner angle rounded.

\section{Etymology}

The new generic name is derived from the Greek leptos meaning thin and Achirus Lacepede, a genus of soles, in reference to the very thin and slender body of the species.

\section{Remarks}

Eschmeyer's Catalog of Fishes (updated to 7 November 2006 at web site HYPERLINK (www.calacademy.org/research/ichthyology/ catalog/fishcatsearch.html) listed 28 genera in the large flatfish family Soleidae. Monroe in Carpenter and Niem (2001) included 17 soleid genera for the western central Pacific. Ochiai (1963) recognized the subfamily Aseraggodinae for four genera: Aseraggodes Kaup, Liachirus Günther, Pardachirus Günther, and Parachirus Matsubara and Ochiai. Randall and Gon (2005) and Randall (2006) placed Parachirus in the synonymy of Aseraggodes and validated the genera Coryphillus Chabanaud and Synclidopus Chabanaud for the subfamily. Ochiai's characters for the Aseraggodinae included a slightly hooked snout (strongly hooked in the Heteromycterinae), caudal fin normally with 18 rays and not joined to the dorsal and anal fins, no pectoral fins, and 9 (actually 10) abdominal vertebrae.

The new genus Leptachirus is most closely related to Aseraggodes. It is separated by its more slender body, the depth 2.7-3.55 in SL, compared to 2.0-2.8 in SL for the species of Aseraggodes; by the more complex cephalic lateralis system of the head, in particular the temporal commissures of the blind side connecting the lateral cephalic branch of the main lateral line and the cephalodorsal line; by the posterior corner of the jaws visible externally on the ocular side (scaled over in Aseraggodes); higher average vertebral count (36-42, compared to 33-39 for Aseraggodes); shorter pelvic fins, with 3 or 4 (rarely 5) pelvic rays (versus 5 in Aseraggodes).

The species of Leptachirus are all from fresh or brackish water, in contrast to those of Aseraggodes, known only from the sea. Figure 1 is a distribution map of the nine species of Leptachirus.

Table 1 Dorsal rays of species of Leptachirus.

\begin{tabular}{|c|c|c|c|c|c|c|c|c|c|c|c|c|c|c|}
\hline & 65 & 66 & 67 & 68 & 69 & 70 & 71 & 72 & 73 & 74 & 75 & 76 & 77 & 78 \\
\hline alleni & 1 & 1 & & 1 & 3 & 6 & 1 & 1 & 2 & & & & & \\
\hline bensbach & & & & & & & 2 & 1 & 1 & 1 & & 1 & & \\
\hline darwinensis & & & & & & & 1 & 1 & 1 & & & & & \\
\hline kikori & 1 & 1 & 3 & 2 & 4 & 2 & 1 & 2 & 3 & 3 & & & & \\
\hline lorentz & & & & 1 & & & 2 & 2 & & & 1 & 1 & & 1 \\
\hline polylepis & & & & & & 1 & 1 & & 2 & 5 & 3 & 2 & 3 & \\
\hline robertsi & & 1 & & 2 & 4 & 3 & 2 & 1 & & 1 & & & & \\
\hline triramus & 1 & 2 & 4 & 2 & 5 & 2 & 1 & 2 & & & & & & \\
\hline
\end{tabular}




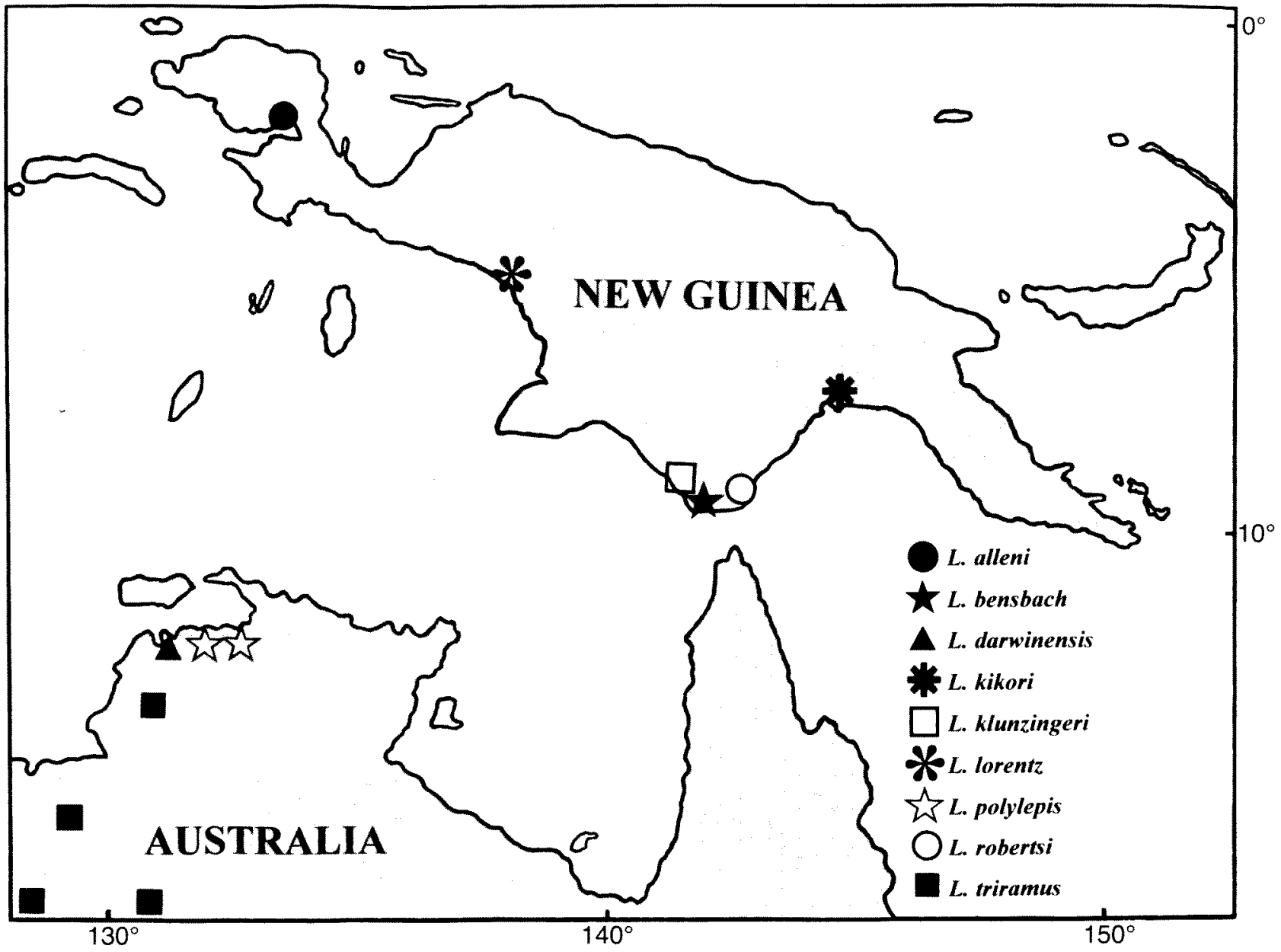

Figure 1 Distribution map of the species of Leptachirus.

Key to the species of Leptachirus

(L. klunzingeri not included in key due to lack of diagnostic information)

1a. Lateral line on ocular side of head divided to three branches (one dorsal, one ventral, and the other continuing horizontally); ocularside pelvic fin attached to genital papilla; eye diameter 4.8-5.5 in HL; lateral-line scales 7184; vertebrae 36-38 (Victoria River, Northern Territory and Ord River, Western Australia)

L. triramus

1b. Lateral line on ocular side of head divided to two branches (one ventral and the other continuing horizontally); ocular-side pelvic fin not attached to genital papilla; eye diameter 5.7-8.4 in $\mathrm{HL}$; lateral-line scales 76111; vertebrae $37-42$

2a. Lateral-line scales 103-111; pelvic rays 4 or 5 (East Alligator, West Alligator, South Alligator, Mary, and Adelaide Rivers, Northern Territory) L. polylepis

2b. Lateral-line scales 76-96; pelvic rays 3 or 4 ... 3

3a. Body depth $33.7-37.1 \%$ SL; anal rays $50-53$; membranes of dorsal and anal fins dark brown except anteriorly (Bintuni River, New Guinea)

L. alleni

3b. Body depth $28.8-33.6 \% \mathrm{SL}$; anal rays $53-59$ (except kikori and robertsi with 50-57); membranes of dorsal and anal fins not dark brown (occasional sections of one or two rays and adjacent membranes may be dark brown, but membranes not entirely dark brown) .... 4

4a. Eyes small, $2.7-3.0 \%$ SL; pelvic fins short, 6.4 $6.9 \%$ SL (Bensbach River, Papua New Guinea)

L. bensbach

$4 \mathrm{~b}$. Eyes not small, $3.0-4.1 \% \mathrm{SL}$; pelvic fins not short, $7.0-8.8 \%$ SL (except lorentz with 6.0 $7.7 \%)$

5

5a. Body depth $28.8-30.8 \%$ SL; vertebrae 40-42 (Lorentz River, New Guinea) L. lorentz

5b. Body depth $30.3-33.2 \%$ SL; vertebrae $38-41 \ldots 6$

6a. Lateral-line scales 90-96; vertebrae 40-41 (modally 41); (East and South Alligator and Adelaide Rivers, Northern Territory)

L. darwinensis

6b. Lateral-line scales 76-88; vertebrae $38-40 \ldots \ldots .7$ 


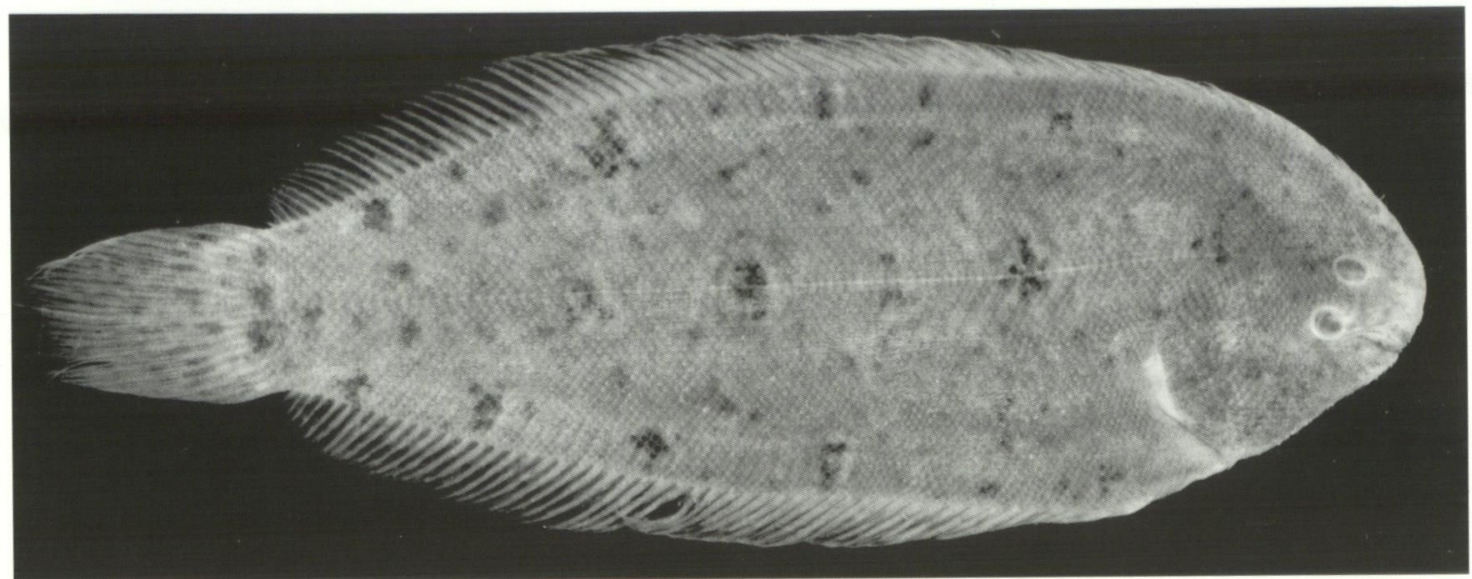

Figure 2 Holotype of Leptachirus alleni sp. nov., WAM P.29959-004, 71.0 mm SL, Bintuni River, New Guinea.

7a. Head short, the length $4.35-4.7$ in SL; length of pelvic fins 7.0-8.2\% SL; upper-jaw length 6.6$7.9 \%$ SL (Kikori River, Papua New Guinea).. L. kikori

7b. Head not short, the length $4.0-4.25$ in SL; length of pelvic fins $8.3-8.8 \%$ SL; upper-jaw length 7.8-8.6\% SL; (Fly River, Papua New Guinea). L. robertsi

\section{Leptachirus alleni sp. nov.}

Figure 2; Tables 1-5

\section{Holotype}

WAM P.29959-004, male, 71.0 mm, New Guinea, Indonesia, Papua Province, Bintuni River, small mangrove creek lined by nipa palm $\left(2^{\circ} 7^{\prime} S\right.$, $\left.133^{\circ} 31^{\prime} \mathrm{E}\right), 0.1-1 \mathrm{~m}$, salinity $10 \mathrm{ppt}$, rotenone and seine, G.R. Allen, 22 March 1989.

\section{Paratypes}

BPBM 40459, 2: 57.7-76.4 mm; NTM 16247-001, 2: 68.2-69.3 mm; USNM 387649, 3: 73.3-78.4 mm; WAM P.29959-015, 6: 57.0-82.5 mm; ZMB 33742, 2: $66.6-86.0 \mathrm{~mm}$, all with same data as holotype.

\section{Diagnosis}

Dorsal rays 65-73; anal rays 50-53; pelvic rays 4; lateral-line scales 82-93; lateral line on ocular side of head with a ventral branch of 4-6 pores, the remaining horizontal anterior part with 5-7 pores; vertebrae 37-39; dorsal pterygiophores anterior to fourth neural spine 8-9; body depth $2.7-3.0$ in SL; caudal peduncle absent; head length 4.35-4.65 in SL; eyes small, the eye diameter 7.2-8.4 in HL; interorbital width 8.1-9.8 in HL; longest dorsal ray $1.75-1.95$ in HL; caudal-fin length $4.0-4.25$ in SL; pelvic fins not joined to genital papilla, their origins adjacent; pelvic fins short, reaching little beyond base of first anal ray, 2.8-3.2 in HL; colour of ocular side in alcohol grey-brown with scattered dark brown spots smaller than eye (most of about pupil size) and three longitudinal rows of larger dark brown blotches; rays of dorsal and anal fins pale, the membranes dark brown (except anteriorly, where pale); caudal fin with pale rays and brown membranes with darker brown spots or longitudinal streaks; a dark brown bar or row of dark spots on caudal-fin base. Largest specimen, $86.0 \mathrm{~mm}$ SL.

\section{Description}

Dorsal rays 73 (65-73), anal rays 53 (50-53), dorsal and anal rays branched at tips except anterior rays (first 18 dorsal rays and first 3 anal rays of holotype unbranched); caudal rays 18, 13 (13-14) branched, 13 (12-13) of these double-branched; pelvic rays 4, none (rarely one) branched; lateral-line scales on ocular side 91 (82-93), including 12 (10-12) between vertical at upper end of gill opening and ventral

Table 2 Anal rays of species of Leptachirus.

\begin{tabular}{|c|c|c|c|c|c|c|c|c|c|c|}
\hline & 50 & 51 & 52 & 53 & 54 & 55 & 56 & 57 & 58 & 59 \\
\hline alleni & 2 & 4 & 5 & 5 & & & & & & \\
\hline bensbach & & & & 1 & 1 & 1 & 2 & & & 1 \\
\hline darwinensis & & & & 1 & 2 & & & & & \\
\hline kikori & 2 & 2 & 4 & 6 & 4 & 1 & 1 & 2 & & \\
\hline lorentz & & & & & 2 & 1 & 2 & 1 & 2 & \\
\hline polylepis & & & & & 2 & 6 & 5 & 2 & 2 & \\
\hline robertsi & 1 & & 2 & 3 & 5 & 1 & 1 & 1 & & \\
\hline triramus & 4 & 3 & 3 & 2 & 3 & 2 & 2 & & & \\
\hline
\end{tabular}


branch of lateral line on head; pores (actually short pored papillae) before ventral branch 4 (2-5); pores of ventral branch 5 (4-6); scales above lateral line on ocular side about 27 , including 1-2 on base of dorsal fin; scales below lateral line about 33 , including $1-2$ on base of anal fin; vertebrae $10+28(9-10+27-29)$ $=38(37-39)$; only erisma before tip of second neural spine; space between second and third neural spines with 6 (4-6) pterygiophores; space between third and fourth neural spines with $3(2-3)$ pterygiophores, hence a total of 9 (8-9) dorsal pterygiophores anterior to fourth neural spine. Ventroanterior margin of urohyal forming angle of about $85^{\circ}\left(80-90^{\circ}\right)$, the inner angle moderately to strongly rounded.

Body depth $2.7(2.7-3.0)$ in SL; body thin, the width 4.75 (4.6-5.05) in body depth; head length 4.75 (4.5-5.05) in SL; no caudal peduncle; depth of caudal-fin base 1.6 (1.55-1.65) in HL; snout not overlapping or projecting anterior to lower lip when mouth closed; snout length 3.4 (3.4-3.8) in HL; preorbital length 3.8 (3.4-3.8) in HL; eyes small, the eye diameter $8.1(7.2-8.4)$ in HL; least vertical interorbital width $8.4(8.1-9.8)$ in $\mathrm{HL}$; upper eye overlapping one-half (one-third to two-thirds) of lower eye; a horizontal line projected anteriorly from upper end of gill opening passing about one eye diameter below lower eye.

Mouth inferior, the jaws strongly curved; maxilla not reaching a vertical through centre of lower eye, the upper-jaw length 3.6 (3.05-3.6) in HL; dense curved band of villiform teeth on blind side of both jaws; tubular anterior nostril at edge of upper jaw in front of dorsal edge of lower eye, not reaching cutaneous edge of eye when laid back, only slightly longer than diameter of its base, and tapering little; posterior nostril an oblique slit in labial groove covered by skin anterior to base of lower eye; anterior nostril of blind side a strongly tapering tubule in a depression above upper lip nearly onehalf distance to end of upper jaw, its length shorter than diameter of its base; posterior nostril of blind side a tapering tubule about two-thirds eye diameter in length dorsoposterior to anterior nostril, the internarial distance equal to cutaneous diameter of eye.

Scales ctenoid on both sides, with 6 to 10 (usually 8 or 9) prominent cteni extending well beyond scale edge; scales on ocular side of snout small, with fewer cteni, losing cteni above anterior nostril, replaced by zone of short fleshy cirri anterior to nostril, some in rows or along low fleshy ridges, and becoming nearly smooth at front edge of snout; scales on blind side of head becoming fleshy with short cteni anteriorly, and replaced by cirri and sensory papillae before posterior end of jaws; eyes separated by $3(2-4)$ rows of scales, with $2-3$ rows of smaller scales extending onto medial edges of eyes; no series of cirri along anterior edge of snout 
Table 4 Vertebrae of species of Leptachirus.

\begin{tabular}{lccccccc}
\hline & 36 & 37 & 38 & 39 & $\mathbf{4 0}$ & $\mathbf{4 1}$ & $\mathbf{4 2}$ \\
\hline $\begin{array}{l}\text { alleni } \\
\text { bensbach }\end{array}$ & 5 & 5 & 6 & & & \\
darwinensis & & & & & 1 & 2 & \\
$\begin{array}{l}\text { kikori } \\
\text { lorentz }\end{array}$ & & & & 13 & 12 & & \\
$\begin{array}{l}\text { polylepis } \\
\text { triramus }\end{array}$ & 1 & 11 & 4 & & 2 & 13 & 3 \\
\hline
\end{tabular}

or ventral edge of head; short slender cirri present on blind side of snout and ventral side of head nearly to edge; a series of about 50 slender cirri along opercular edge of gill opening of blind side, but none on ocular side except for a few short ones ventrally.

Lateral line straight on both sides along middle of body, with a short ventral preopercular branch on ocular side of head, the straight anterior part projecting toward upper eye; a thin cephalodorsal sensory line on ocular side from front of snout, passing posteriorly below base of dorsal fin and indistinctly onto anterior body; lateral line extending with pores into caudal fin about threefourths distance to posterior fin margin; sensory pores and cirri on blind side of head as described for genus, with about 13 temporal commissures linking dorsal branch of main lateral line on head with cephalodorsal line along base of dorsal fin.

Basal sheath of one or two rows of small scales on dorsal and anal fins; base of caudal fin with rows of progressively smaller scales extending out on fin; tiny scales, still with cteni, continuing out on rays more than half way to posterior margin; dorsal and anal rays on both sides with a thin membranous ridge extending more than half way to ray tips (less developed posteriorly); no cirri on edges of ridges; distal ends of anterior dorsal rays not filamentous.

Origin of dorsal fin anterior to ventral edge of upper eye, the predorsal length $4.3(4.1-4.6)$ in $\mathrm{HL}$; first dorsal ray $3.8(3.55-4.2)$ in HL; longest dorsal ray $1.95(1.75-1.95)$ in $\mathrm{HL}$; origin of anal fin below base of nineteenth dorsal ray, the preanal length 3.9 $(4.0-4.3)$ in SL; first anal ray $4.05(3.15-4.5)$ in HL; longest anal ray 1.95 (1.75-1.95) in HL; anus anterior to first anal ray; genital papilla at base of first anal ray, dorsoposterior to anus; caudal fin 4.15 (4.0-4.25) in SL; origins of pelvic fins adjacent; pelvic fins not diverging posteriorly, the last membrane of each fin ending at base of anal papilla; second and third pelvic rays longest, reaching at most slightly posterior to base of first anal ray, 3.2 (2.8-3.1) in HL.

Colour of ocular side of holotype in alcohol greybrown with scattered dark brown spots smaller than eye (most of about pupil size) and three longitudinal rows of larger dark brown blotches: one of seven blotches below dorsal fin, one of six above base of anal fin, and the third of two largest blotches on lateral line, with smaller blotches on the line; an irregular broad dark brown bar at base of caudal fin; lateral line pale; rays and membranes of about first third of dorsal fin pale; membranes of

Table 5 Proportional measurements of type specimens of Leptachirus alleni as percentages of the standard length.

\begin{tabular}{lcrrrrrr}
\hline & Holotype & \multicolumn{7}{c}{ Paratypes } \\
& WAM & WAM & WAM & WAM & WAM & WAM & WAM \\
& P.29959 & P.29959 & P.29959 & P.29959 & P.29959 & P.29959 & P.29959 \\
\hline Standard length (mm) & 71.0 & 57.0 & 66.3 & 68.8 & 73.9 & 80.1 & 82.5 \\
Body depth & 37.1 & 33.2 & 34.8 & 33.7 & 33.9 & 36.9 & 36.5 \\
Body width & 7.8 & 6.6 & 7.6 & 7.5 & 6.7 & 7.9 & 7.9 \\
Head length & 22.7 & 21.5 & 22.6 & 22.2 & 22.3 & 23.0 & 21.8 \\
Snout length & 7.6 & 7.2 & 7.5 & 7.7 & 7.4 & 7.6 & 7.5 \\
Preorbital length & 6.0 & 6.2 & 6.1 & 6.5 & 6.4 & 6.1 & 6.3 \\
Eye diameter & 2.8 & 2.7 & 3.0 & 2.8 & 3.1 & 3.1 & 2.6 \\
Interorbital width & 2.7 & 2.2 & 2.8 & 2.5 & 2.4 & 2.5 & 2.6 \\
Upper-jaw length & 6.3 & 7.0 & 6.4 & 6.2 & 6.8 & 7.3 & 6.7 \\
Depth of caudal-fin base & 14.3 & 14.0 & 14.4 & 13.8 & 14.3 & 13.9 & 14.0 \\
Predorsal length & 5.3 & 5.1 & 5.3 & 5.4 & 5.3 & 5.0 & 4.8 \\
Preanal length & 25.8 & 24.6 & 24.7 & 23.2 & 23.3 & 24.9 & 25.1 \\
Prepelvic length & 21.1 & 17.6 & 19.0 & 18.3 & 19.3 & 18.7 & 18.8 \\
First dorsal ray & 6.0 & 6.1 & 5.8 & 5.9 & 5.4 & 6.2 & 5.2 \\
Longest dorsal ray & 11.5 & 12.4 & 11.7 & 11.9 & 11.8 & 11.7 & 11.9 \\
First anal ray & 5.6 & 6.8 & 5.5 & 6.6 & 6.7 & 5.1 & 5.8 \\
Longest anal ray & 11.5 & 12.3 & 11.9 & 12.1 & 11.9 & 12.1 & 12.0 \\
Caudal-fin length & 24.0 & 24.9 & 23.4 & 24.0 & 23.7 & 24.9 & 24.9 \\
Pelvic-fin length & 7.1 & 7.0 & 7.4 & 8.0 & 7.7 & 7.7 & 7.3 \\
\hline
\end{tabular}

The full museum number for the holotype is WAM P.29959-004; for the six paratypes, WAM P.29959-015. 
remainder of fin progressively darker posteriorly, becoming dark brown on about posterior half of fin anal fin similar but entirely pale on only anterior fifth of fin; caudal fin with pale rays and brown membranes with small darker brown spots and longitudinal streaks; pelvic fins pale; exposed gill membranes whitish. Colour of blind side yellowish white, the dorsal and anal fins now more contrastingly dark.

\section{Etymology}

This species is named for Gerald R. Allen who collected the type specimens, as well as many other specimens reported in this study.

\section{Remarks}

The 16 type specimens of this species were collected at the same site, a small turbid creek with a salinity of $10 \mathrm{ppt}$ about $19 \mathrm{~km}$ upstream from Bintuni Bay. The area receives semidiurnal tides averaging about $3.5 \mathrm{~m}$. The mangrove-nipa zone of this creek is therefore subjected to large fluctuations in salinity and turbidity (Erftemeijer et al. 1989).

As will be noted in Tables 1 and 3, Leptachirus alleni has a wide range in the numbers of dorsal rays and lateral-line scales ( 9 for the dorsal rays and 10 for the lateral-line scales). Large variation in these counts is characteristic of species of the genus and those of the allied genus Aseraggodes. The counts of anal rays are not so variable. The anal-ray count for L. alleni, 50-53, is the lowest on average for the genus (Table 2).

Three specimens (NTM S.14857-001, 62.6-79.5 $\mathrm{mm}$ ) from the Mawati Estuary of Papua Province, New Guinea $\left(4^{\circ} 57.7^{\prime} \mathrm{S}, 137^{\circ} 7.5^{\prime} \mathrm{E}\right)$ are identified as Leptachirus alleni. They agree with the above description, but were not included among the paratypes because of the distance of that locality from the Bintuni River area.

\section{Leptachirus bensbach sp. nov.}

Figure 3; Tables 1-4,6

\section{Holotype}

WAM P.27820-003, female, $69.4 \mathrm{~mm}$, Papua New Guinea, Bensbach River, $12 \mathrm{~km}$ downstream of Balamuk, $8^{\circ} 59^{\prime}$ S, $141^{\circ} 14^{\prime} \mathrm{E}$, seine, G.R. Allen and J. Paska, 30 September 1982.

\section{Paratypes}

BPBM 40462, $74.6 \mathrm{~mm}$ and WAM P.27820-007, $67.5 \mathrm{~mm}$, collected with holotype; WAM P.27822004, 2: 76.2-96.5 mm, Papua New Guinea, Bensbach River, $2 \mathrm{~km}$ upstream from Bensbach Wildlife Lodge, $8^{\circ} 52^{\prime} \mathrm{S}, 141^{\circ} 12^{\prime} \mathrm{E}$, rotenone, G.R. Allen and J. Paska, 1 October 1982; WAM 31342-001, 107.8 mm, Bensbach River, vicinity of Bensbach Wildlife Lodge, G. Hitchcock, May, 1997.

\section{Diagnosis}

Dorsal rays $71-76$; anal rays $53-59$; pelvic rays 3 or 4; lateral-line scales 88-95; lateral line on ocular side of head with a ventral branch of 4 to 9 pores, the remaining horizontal anterior part with 5-7 pores; vertebrae 40-41 (modally 40); dorsal pterygiophores anterior to fourth neural spine 8; body depth 3.0-3.45 in SL; caudal peduncle absent or extremely short; head length 4.35-4.7 in SL; eyes small, the eye diameter 7.35-8.5 in HL; interorbital width $9.3-13.7$ in HL; longest dorsal ray 1.85-1.95 in HL; caudal fin 4.3-4.6 in SL; pelvic fins not joined to genital papilla, their origins adjacent; pelvic fins short, reaching little beyond base of first anal ray, 2.8-3.2 in HL; colour of ocular side light brown mottled with small darker brown blotches; three longitudinal rows of dark brown blotches of one to two eye diameters in size; dorsal and anal fins with indistinct brown spots centred on single rays and membrane to each side; caudal fin pale yellowish with a row of dark brown spots at base and small fainter spots on basal half of fin. Largest specimen, $107.8 \mathrm{~mm}$ SL.

\section{Description}

Dorsal rays 72 (71-76), anal rays 53 (54-59), dorsal and anal rays branched distally except anterior rays (first 15 dorsal rays and first 2 anal rays of holotype unbranched); caudal rays 18, 14 branched, 12 (1214) of these double-branched; pelvic rays $3(3-4)$, none branched; lateral-line scales on ocular side 90 (88-95), including 11 (11-13) between a vertical at upper end of gill opening and ventral branch of lateral line on head; pores before ventral branch 3 $(2-5)$; pores of ventral branch 7 (5-9); scales above lateral line on ocular side about 27 , including 1-2 on base of dorsal fin; scales below lateral line about 33 , including 1-2 on base of anal fin; vertebrae $10+$ $31(10+30-31)=41(40-41$, modally 40$)$; only erisma before tip of second neural spine; space between second and third neural spines with 6 (5) pterygiophores; space between third and fourth neural spines with $2(2-3)$ pterygiophores, hence a total of 9 (8-9) dorsal pterygiophores anterior to fourth neural spine. Ventroanterior margin of urohyal forming an angle of about $85^{\circ}\left(80-100^{\circ}\right)$, the inner angle moderately to strongly rounded.

Body depth $3.0(3.0-3.45)$ in SL; body thin, the width 4.8 (3.8-4.6) in body depth; head length 4.35 (4.45-4.7) in SL; caudal peduncle absent, except on holotype and one paratype where extremely short; depth of caudal-fin base 1.7 (1.7-1.95) in HL; snout not overlapping or projecting anterior to lower lip when mouth closed; snout length 3.05 (2.75-3.2) in HL; preorbital length 3.75 (3.4-4.1) in HL; eyes small, the eye diameter 7.65 (7.35-8.5) in HL; least vertical interorbital width 13.5 (9.3-13.8) in HL; upper eye overlapping two-thirds (one-third to three-fourths) of lower eye; a horizontal line 


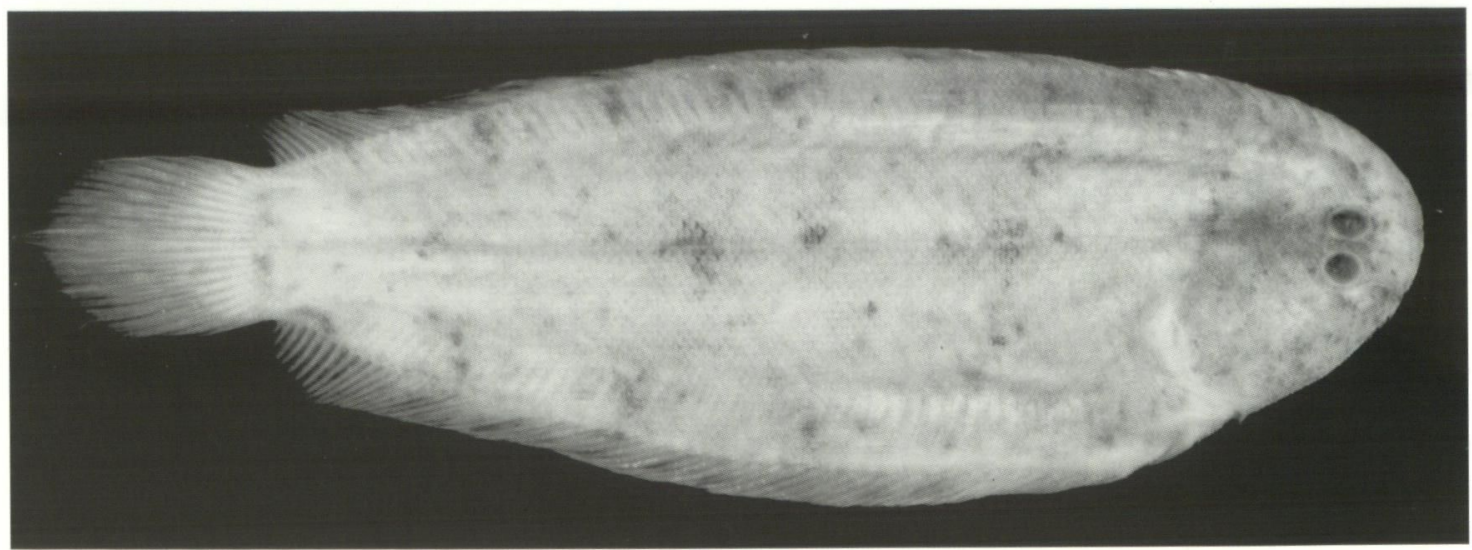

Figure 3 Holotype of Leptachirus bensbach sp. nov., WAM P.27820-003, 69.4 mm SL, Bensbach River, Papua New Guinea.

projected anteriorly from upper end of gill opening passing about one eye diameter below lower eye.

Mouth inferior, the jaws strongly curved; maxilla reaching vertical through anterior margin of pupil of lower eye (below centre of eye in largest paratype), the upper-jaw length 3.8 (3.3-3.6) in HL; a dense curved band of villiform teeth on blind side of both jaws; tubular anterior nostril in a slight depression above upper lip in front of dorsal edge of lower eye, not reaching cutaneous edge of eye when laid back, its length only slightly longer than diameter of its base, and tapering only slightly; posterior nostril an oblique slit in labial groove covered by skin anterior to base of lower eye; anterior nostril of blind side a strongly tapering tubule in a depression above upper lip nearly onehalf distance to end of upper jaw, its length shorter than diameter of its base; posterior nostril of blind side a tapering tubule about two-thirds eye diameter in length, dorsoposterior to anterior nostril, the internarial distance equal to cutaneous diameter of eye.

Scales ctenoid on both sides, with $7-11$ (usually 8 or 9) cteni, extending well beyond scale edge; scales on ocular side of snout before eyes small, with fewer cteni, replaced before anterior nostril with rows of small papillae and cirri; scales on blind side of head becoming fleshy with short cteni anteriorly, and replaced by cirri and sensory papillae before posterior end of jaws; a row of very small papillae at edge of depression containing anterior nostril (except ventrally); eyes separated by 2 (1-3) rows of scales, with 2-4 rows of smaller scales extending onto medial edges of eyes; no series of cirri directly on anterior edge of snout or ventral edge of head; short slender cirri on blind side of snout and ventral side of head nearly to edge; a series of about 25 slender cirri along opercular edge of gill opening of blind side of holotype, but none on ocular side except for a few short ones ventrally.

Lateral line straight on both sides along middle of body, with a short ventral preopercular branch on ocular side of head, the straight anterior part projecting toward upper eye; a cephalodorsal sensory line on ocular side from front of snout, passing posteriorly below base of dorsal fin and indistinctly onto anterior body; lateral line extending with pores into caudal fin along dorsal edge of tenth ray more than three-fourths distance to posterior fin margin; cephalic sensory system of blind side as described for genus, with about 13 temporal commissures (sensory lines alternating with bands of cirri) dorsal cephalic branch of lateral line with cephalodorsal line along base of dorsal fin.

Basal sheath of one or two rows of small scales on dorsal and anal fins; base of caudal fin with rows of progressively smaller scales extending about halfway out on fin; tiny scales, still with cteni, continuing out on rays more than halfway to posterior margin; dorsal and anal rays on both sides with a thin membranous ridge extending more than halfway to ray tips; no cirri on edges of membranous ridges; only tips of anterior dorsal rays free of membrane.

Origin of dorsal fin anterior to ventral part of upper eye, the predorsal length 4.6 (4.1-4.6) in $\mathrm{HL}$; first dorsal ray $3.35(3.15-3.8)$ in HL; longest dorsal ray 1.85 (1.85-1.95) in HL; origin of anal fin below base of seventeenth dorsal ray, the preanal length 4.2 (4.25) in SL; first anal ray $3.4(3.1-4.2)$ in $\mathrm{HL}$; longest anal ray 1.75 (1.8-1.9) in HL; anus anterior to first anal ray; genital papilla at base of first anal ray, dorsoposterior to anus; caudal fin 4.3 (4.3-4.6) in SL; pelvic fins not attached to genital papilla, their origins adjacent; pelvic fins not diverging posteriorly, the last membrane of each fin ending near base of anal papilla; second pelvic ray longest, reaching base of first anal ray, 3.6 (3.3-3.6) in HL.

Colour of ocular side of holotype in alcohol light brown, finely mottled with small darker brown blotches; a row of 11 dark brown blotches of one to two eye-diameter size along base of dorsal fin, a row of six similar blotches above base of anal fin, 
Table 6 Proportional measurements of type specimens of Leptachirus bensbach as percentages of the standard length.

\begin{tabular}{|c|c|c|c|c|c|}
\hline & \multirow{2}{*}{$\begin{array}{c}\text { Holotype } \\
\text { WAM P.27820 }\end{array}$} & \multicolumn{4}{|c|}{ Paratypes } \\
\hline & & ВРBM 40462 & WAM P.27822 & WAM P.27822 & WAM P.31342 \\
\hline Standard length (mm) & 69.4 & 74.6 & 76.2 & 96.5 & 107.8 \\
\hline Body depth & 32.9 & 29.0 & 30.9 & 33.2 & 33.6 \\
\hline Body width & 6.9 & 6.5 & 6.7 & 8.3 & 8.8 \\
\hline Head length & 22.9 & 22.5 & 21.3 & 22.9 & 22.0 \\
\hline Snout length & 7.5 & 7.4 & 7.8 & 7.2 & 6.9 \\
\hline Preorbital length & 6.1 & 6.4 & 6.3 & 5.6 & 5.5 \\
\hline Eye diameter & 3.0 & 2.8 & 2.8 & 2.7 & 2.7 \\
\hline Interorbital width & 1.7 & 1.7 & 2.3 & 2.1 & 1.6 \\
\hline Upper-jaw length & 6.0 & 6.3 & 6.5 & 6.8 & 6.2 \\
\hline Caudal-peduncle depth & 13.5 & 11.9 & 12.4 & 11.8 & 13.0 \\
\hline Caudal-peduncle length & 0.1 & 0.1 & 0 & 0 & 0 \\
\hline Predorsal length & 5.0 & 4.5 & 5.2 & 5.2 & 4.6 \\
\hline Preanal length & 24.0 & 23.5 & 23.4 & 23.7 & 23.7 \\
\hline Prepelvic length & 20.9 & 19.9 & 19.3 & 19.9 & 19.3 \\
\hline First dorsal ray & 6.8 & 6.7 & 6.8 & 6.0 & 5.9 \\
\hline Longest dorsal ray & 12.3 & 11.9 & 11.5 & 11.8 & 11.4 \\
\hline First anal ray & 6.7 & 7.3 & 5.8 & 6.6 & 5.2 \\
\hline Longest anal ray & 12.9 & 11.9 & 11.6 & 12.3 & 12.2 \\
\hline Caudal-fin length & 23.2 & 23.1 & 22.3 & 23.3 & 21.7 \\
\hline Pelvic-fin length & 6.9 & 6.7 & 6.5 & 6.4 & 6.5 \\
\hline
\end{tabular}

The full museum number for the holotype is WAM P.27820-003; for the paratypes, WAM P.27822-004 and WAM P.31342-001.

and five along lateral line on body, the first with peripheral small dark spots; a large dark blotch at anterior end of lateral line, and another shaped like a hand on abdomen; dorsal and anal fins pale yellowish with a series of indistinct large brown blotches on single rays and adjacent membrane; caudal fin pale yellowish with a row of brown blotches across base and faint smaller blotches in basal half of fin; pelvic fins pale. Colour of blind side yellowish white.

\section{Etymology}

This species is named for the Bensbach River at the southwestern corner of Papua New Guinea, the locality for all specimens examined. The species name is treated as a noun in apposition.

\section{Remarks}

All specimens of Leptachirus bensbach examined were collected from freshwater (G.R. Allen, pers. comm.).

Leptachirus bensbach was first identified as Aseraggodes klunzingeri, like other soles of this genus from rivers of the south coast of New Guinea. The Bensbach River is only $100 \mathrm{~km}$ southeast of the mouth of the Merauke River, the type locality of $L$. klunzingeri, and is the closest of any locality to the Merauke River from which specimens of this genus have been collected. However, $L$. bensbach is clearly not klunzingeri, judging from the much deeper body of the latter shown in the very good illustration of the species provided by Weber (1908).
Also, the dorsal-ray counts of 67-70 and lateral-line scale counts of $80-85$ given by Weber for klunzingeri are too low for $L$. bensbach. Weber had only one specimen of $L$. klunzingeri, which is not extant. The range of his counts included specimens of another species.

No measurements were taken of the $67.5-\mathrm{mm}$ specimen of WAM P.27820-007, collected with the holotype, because the body was too strongly curved when preserved.

The most similar species to Leptachirus bensbach is $L$. lorentz, best separated on eye size and modal vertebral count.

\section{Leptachirus darwinensis sp. nov.} Figure 4; Tables 1-4, 7

\section{Holotype}

NTM S.10618-001, male, $70.0 \mathrm{~mm}$, Australia, Northern Territory, East Alligator River, $3 \mathrm{~km}$ upstream from Cahills Crossing, $12^{\circ} 27^{\prime} \mathrm{S}, 132^{\circ} 58^{\prime} \mathrm{E}$, G. Miles, June, 1977.

\section{Paratypes}

NTM S.10868-001, $66.2 \mathrm{~mm}$, Northern Territory, East Alligator River, Cannon Hill Lagoon, $12^{\circ} 24^{\prime} \mathrm{S}$, $132^{\circ} 58^{\prime}$ E, S.H. Midgley, 26 September 1972; BPBM 40477, $61.8 \mathrm{~mm}$, Northern Territory, South Alligator River, Jim Jim Creek, $100 \mathrm{~m}$ from Pine Creek Road, $12^{\circ} 57^{\prime} \mathrm{S}, 132^{\circ} 47^{\prime} \mathrm{E}, \mathrm{P}$. Wellings, 18 October 1984; NTM S.15583-001, $64.8 \mathrm{~mm}$, Northern Territory, Adelaide River, Marrakai Creek, $12^{\circ} 40.71$ 'S, 


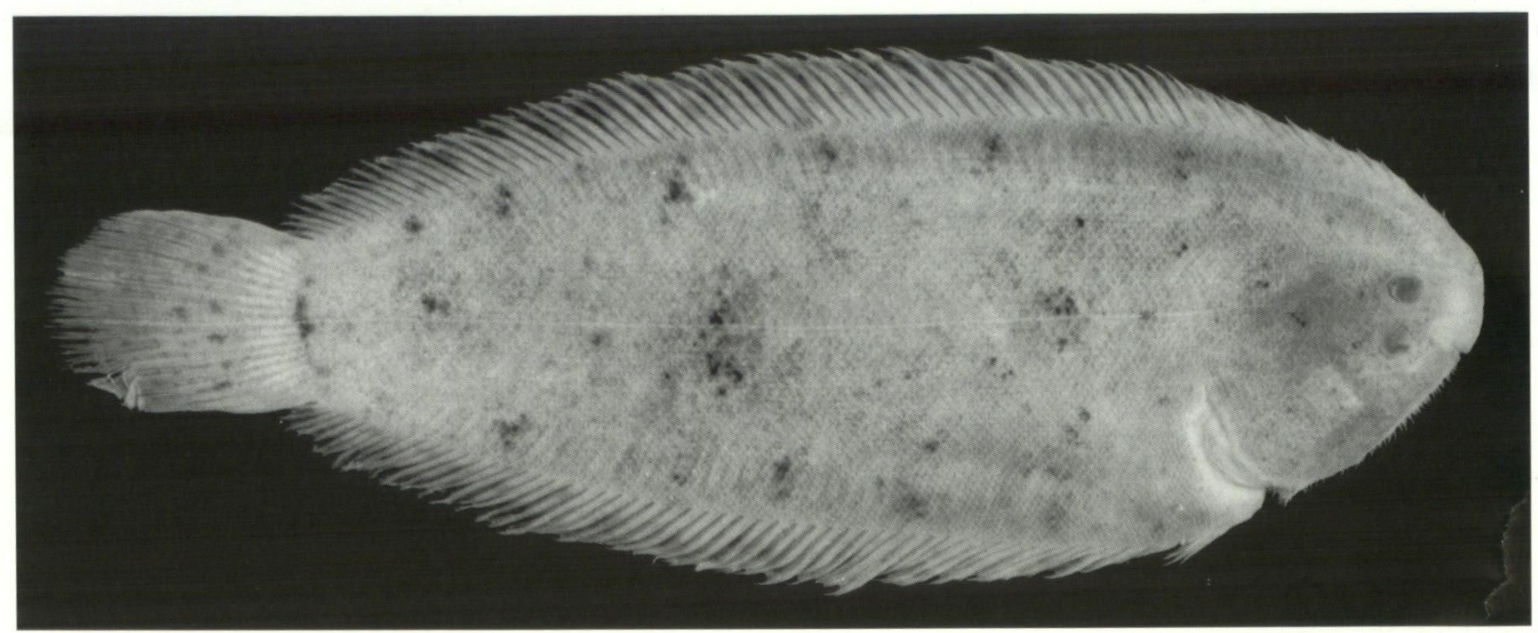

Figure 4 Holotype of Leptachirus darwinensis sp. nov., NTM S.10618-001, 70.0 mm SL, East Alligator River, Northern Territory, Australia.

$131^{\circ} 20.09^{\prime} \mathrm{E}, 3-4 \mathrm{~m}, \mathrm{~T}$. Berra and Q. Allsop, 3 July 2001; NTM S.16036-001, 68.7 mm, Northern Territory, Adelaide River, Arnhem Highway boat ramp, $12^{\circ} 39.42^{\prime} \mathrm{S}, 131^{\circ} 20.18^{\prime} \mathrm{E}, 0-0.5 \mathrm{~m}$, S. Gregg, 8 January 2005.

\section{Diagnosis}

Dorsal rays 71-73; anal rays 53-56; pelvic rays 4; lateral-line scales 90-96; lateral line on ocular side of head with a ventral branch of 4-9 pores, the remaining horizontal anterior part with 5-7 pores; vertebrae 40-41; dorsal pterygiophores anterior to fourth neural spine 8-9; body depth 3.1-3.2 in SL; caudal peduncle absent; head length $4.3-4.6$ in SL; eyes small, the eye diameter $6.8-7.7$ in HL; interorbital width 9.3-10.8 in HL; longest dorsal ray 1.85-1.95 in HL; caudal fin 4.1-4.35 in SL; pelvic fins not joined to genital papilla, their origins adjacent; pelvic fins short, reaching little beyond base of first anal ray, 2.75-3.05 in HL; colour of ocular side light brown mottled with small darker brown blotches; three longitudinal rows of dark brown blotches of one to two eye diameters in size; dorsal and anal fins with indistinct brown spots centred on single rays and membrane to each side; caudal fin pale yellowish with of dark brown spots at base and transverse rows of progressively smaller and fainter spots in distal two-thirds of fin. Largest specimen, $68.7 \mathrm{~mm}$ SL.

\section{Description}

Dorsal rays 72 (71-73), anal rays 54 (53-56), dorsal and anal rays branched distally except anterior rays (first 17 dorsal rays and first 2 anal rays of holotype unbranched); caudal rays 18, 14 branched, 12 (1112) of these double-branched; pelvic rays 4 , none branched; lateral-line scales on ocular side 91 (9096), including $10(10-12)$ between a vertical at upper end of gill opening and ventral branch of lateral line on head; pores before ventral branch 5 (3-4); pores of ventral branch $9(6-8)$; scales above lateral line on ocular side about 31, including 2-3 on base of dorsal fin; scales below lateral line about 36 , including 2-3 on base of anal fin; vertebrae $10+31$ $(10+30-31)=41(40-41)$; only erisma before tip of second neural spine; space between second and third neural spines with 5(5) pterygiophores; space between third and fourth neural spines with 2 (2-3) pterygiophores, hence a total of 8 (8-9) dorsal pterygiophores anterior to fourth neural spine. Ventroanterior margin of urohyal forming an angle of about $100^{\circ}\left(85-90^{\circ}\right)$, the inner angle strongly rounded.

Body depth 3.2 (3.1-3.2) in SL; body thin, the width 4.1 (3.8-5.35) in body depth; head length 4.3 (4.3-4.6) in SL; caudal peduncle absent; depth of caudal-fin base 1.7 (1.65-1.75) in HL; snout not overlapping lower jaw, but upper lip projecting slightly ventroanterior to lower lip; snout length 3.3 (3.0-3.15) in HL; preorbital length 3.45 (3.45-3.85) in HL; eyes small, the eye diameter 7.25 (6.8-7.7) in $\mathrm{HL}$; least vertical interorbital width 10.1 (9.3-10.8) in HL; upper eye overlapping two-thirds (one-third to one-half) of lower eye; a horizontal line projected anteriorly from upper end of gill opening passing about one eye diameter below lower eye.

Mouth inferior, the jaws strongly curved; maxilla reaching vertical through anterior margin of pupil of lower eye, the upper-jaw length 3.3 (3.15-3.35) in HL; a dense curved band of villiform teeth on blind side of both jaws; tubular anterior nostril in slight depression above upper lip in front of dorsal edge of lower eye, not reaching cutaneous edge of eye when laid back, its length no longer than diameter of its base, and not tapering; posterior nostril an oblique slit in labial groove covered by skin anterior to base of lower eye; anterior nostril of blind side a strongly tapering tubule in a depression above 
upper lip nearly one-half distance to end of upper jaw, its length shorter than diameter of its base; posterior nostril of blind side a tapering tubule about half eye diameter in length, dorsoposterior to anterior nostril, the internarial distance equal to diameter of eye.

Scales ctenoid on both sides, with 8-12 (usually 9 or 10) cteni, not extending well beyond scale edge; scales on ocular side of snout before eyes small, with fewer cteni, becoming fleshy above anterior nostril; and replaced anterior to nostril by smooth translucent tissue with small dark brown inclusions (partially free as small dark papillae and dark cirri on three paratypes); scales of blind side dorsally on body and on head with fewer and shorter cteni, losing cteni at level of preopercle and becoming more fleshy, with cirri and sensory papillae before posterior end of jaws; a row of very small papillae dorsally at edge of depression containing anterior nostril on ocular side of head; eyes separated by 4 (2-4) rows of scales, with $3-5$ rows of smaller scales extending onto medial edges of eyes; no series of cirri directly on anterior edge of snout or ventral edge of head; short slender cirri on blind side of snout and ventral side of head nearly to edge; a series of slender cirri along opercular edge of gill opening of blind side ( 24 in holotype), but few on ocular side (holotype with most, 10).

Lateral line straight on both sides along middle of body, with a short ventral preopercular branch on ocular side of head, the straight anterior part projecting toward upper eye; cephalodorsal sensory line on ocular side of head faint; lateral line extending with pores into caudal fin along dorsal edge of tenth ray more than three-fourths distance to posterior fin margin; cephalic sensory system of blind side as described for genus, with about 16 temporal commissures (sensory rows of papillae alternating with bands of cirri) between dorsal cephalic branch of lateral line with cephalodorsal line along base of dorsal fin, the latter extending about half way back on body.

A basal sheath of two to three rows of small scales on dorsal and anal fins; base of caudal fin with rows of progressively smaller scales extending about halfway out on fin; tiny scales, still with cteni, continuing out on rays more than halfway to posterior margin; dorsal and anal rays on both sides with a membranous ridge extending more than halfway to ray tips; small partially embedded scales extending out on ridges, but no cirri on edges; only tips of anterior dorsal rays free of membrane.

Origin of dorsal fin anterior to ventral part of upper eye, the predorsal length $5.3(4.05-4.8)$ in $\mathrm{HL}$; first dorsal ray $3.2(3.1-3.2)$ in $\mathrm{HL}$; longest dorsal ray $1.9(1.85-1.95)$ in $\mathrm{HL}$; origin of anal fin in line with posterior end of gill opening and base of seventeenth dorsal ray, the preanal length 4.15 (4.05-4.2) in SL; first anal ray $3.4(3.25-3.4)$ in HL; longest anal ray $1.9(1.85-1.9)$ in HL; anus anterior to first anal ray; genital papilla at base of first anal ray, dorsoposterior to anus; caudal fin 4.25 (4.14.35 ) in SL; pelvic fins not attached to genital papilla, their origins adjacent; pelvic fins not diverging posteriorly, the last membrane of each fin ending near base of anal papilla; second pelvic ray longest, reaching base of first anal ray, 3.05 (2.753.0) in HL.

Table 7 Proportional measurements of type specimens of Leptachirus darwinensis as percentages of standard length.

\begin{tabular}{lcrrrr}
\hline & Holotype & \multicolumn{3}{c}{ Paratypes } \\
& NTM S.10618 & BPBM 40477 & NTM S.15583 & NTM S.10868 & NTM S.16036 \\
\hline Standard length (mm) & 70.0 & 61.8 & 64.8 & 66.2 & 68.7 \\
Body depth & 31.4 & 31.5 & 32.3 & 31.9 & 32.2 \\
Body width & 7.7 & 7.4 & 8.5 & 6.8 & 6.0 \\
Head length & 23.2 & 22.7 & 21.7 & 22.3 & 23.1 \\
Snout length & 7.1 & 7.6 & 6.9 & 7.1 & 7.4 \\
Preorbital length & 6.7 & 6.5 & 6.3 & 5.9 & 6.0 \\
Eye diameter & 3.2 & 3.3 & 3.2 & 3.0 & 3.0 \\
Interorbital width & 2.3 & 2.1 & 2.3 & 2.4 & 2.4 \\
Upper-jaw length & 7.0 & 7.1 & 6.5 & 7.1 & 6.1 \\
Depth of caudal-fin base & 13.7 & 13.0 & 13.1 & 13.6 & 13.2 \\
Predorsal length & 4.4 & 5.1 & 4.5 & 5.5 & 5.0 \\
Preanal length & 24.0 & 23.7 & 23.8 & 24.1 & 24.7 \\
Prepelvic length & 20.0 & 18.0 & 18.5 & 19.6 & 19.3 \\
First dorsal ray & 7.3 & 7.3 & 7.2 & 7.0 & 7.2 \\
Longest dorsal ray & 12.2 & 11.5 & 11.8 & 11.7 & 11.8 \\
First anal ray & 6.8 & 6.9 & 6.4 & 6.8 & 7.1 \\
Longest anal ray & 12.4 & 11.8 & 12.2 & 12.0 & 12.3 \\
Caudal-fin length & 23.6 & 22.9 & 23.1 & 24.3 & 23.3 \\
Pelvic-fin length & 7.6 & 8.2 & 7.5 & 8.0 & 7.7 \\
\hline
\end{tabular}

All the above NTM-S museum numbers end with -001. 
Colour of ocular side of holotype in alcohol finely mottled grey-brown with three longitudinal rows of dark brown spots: one of six to seven spots of eye size or smaller below base of dorsal and anal fins, and the third of five spots along lateral line, the second, third, and fifth consisting of small dark brown spots within an obscure dark grey blotch; gill membranes pale; dorsal and anal fins pale with some dusky pigment on membranes and basally on rays, and a series of indistinct dark spots in outer part of about posterior two-thirds of fins, most consisting of dark pigment concentration on one ray and adjacent membranes; caudal fin pale with a dark brown spot at midbase as part of the fifth dark lateral-line blotch; a series of irregular transverse rows of dusky spots on rays, progressively smaller and fainter distally; colour of blind side pale yellowish.

\section{Etymology}

This species is named darwinensis for the city of Darwin in the Northern Territory for its proximity to the three rivers to the east in which specimens have been collected.

\section{Remarks}

The holotype was collected upstream from Cahills Crossing of the East Alligator River, a freshwater site. Paratype localities of Cannon Hill Lagoon of the East Alligator River, Jim Jim Creek of the South Alligator River, and Marrakai Creek of the Adelaide River are also freshwater areas. The Arnhem Highway boat ramp, about $60 \mathrm{~km}$ from the mouth of the Adelaide River, may be slightly brackish. A salinity reading of $0.2 \mathrm{ppt}$ was taken on an incoming tide (Gavin Dally, pers. comm.).

Leptachirus darwinensis is one of a closely related group of seven species, only one of which, $L$. polylepis, also occurs in rivers of the Northern Territory. The eighth species of the genus, $L$. triramus from the Victoria and Ord Rivers of northern Australia, is clearly distinct from the other seven. L. darwinensis is easily distinguished from L. polylepis by the much lower lateral-line scale count. Of the remaining five similar species, all from rivers or estuaries of southern New Guinea, $L$. darwinensis is clearly closest to $L$. bensbach. The dorsal- and anal-ray counts of $L$. darwinensis are within the range for L. bensbach, and the lateralline scale counts are broadly overlapping. The vertebral count is modally the same as that of $L$. lorentz and L. polylepis, but one more than the count of $L$. bensbach (Table 4). Morphometric data for $L$. bensbach and $L$. darwinensis reveal only a difference in the pelvic-fin length, that of $L$. darwinensis being consistently longer, and eye size. The eye of $L$. bensbach is larger; however, all but one of the specimens are larger than those of $L$. darwinensis, which could account for this difference. The dark spots of the three longitudinal series of $L$. bensbach are generally much larger than those of $L$. darwinensis. The most convincing separation is the size of the cteni of the scales. When specimens of equal size are compared, the cteni of $L$. bensbach are clearly longer.

\section{Leptachirus kikori sp. nov.} Figure 5; Tables $1-4,8$

\section{Holotype}

WAM P.31210-002, male, $71.6 \mathrm{~mm}$, Papua New Guinea, Kikori River, $4 \mathrm{~km}$ southwest of Ero village, $728^{\prime} \mathrm{S}, 144^{\circ} 26^{\prime} \mathrm{E}$, mud and nipa palm roots, $0.1-2 \mathrm{~m}$, rotenone, G.R. Allen and T. Leary, 4 November 1996.

\section{Paratypes}

WAM P.30977-020, 13: 24.0-58.4 mm, Papua New Guinea, Kikori River, Waimake Creek, about $5 \mathrm{~km}$ up creek from Veiru village, $7^{\circ} 26^{\prime} \mathrm{S}, 144^{\circ} 12^{\prime} \mathrm{E}, 0-2 \mathrm{~m}$, rotenone, G.R. Allen, 5 March 1995; BPBM 40466, 3 : 26.5-57.0 mm, NTM S.16250-001, 3: 26.3-5.2 mm, USNM 387207, 3: 37.4-57.1 mm, ZMB 33746, 3: 26.6$56.3 \mathrm{~mm}$, same data as preceding; WAM P.31210 $018,6: 26.7-43.2 \mathrm{~mm}$, same data as holotype.

\section{Diagnosis}

Dorsal rays 65-74; anal rays 50-57; pelvic rays 4; lateral line on ocular side of head with a ventral branch of 5-8 pored scales, the remaining horizontal anterior part with 3-5 pored scales; lateral-line scales to point of branching on head 76-88, including 8-10 anterior to upper end of gill opening; vertebrae 39-40; dorsal pterygiophores anterior to fourth neural spine 8-9 (usually 9); body slender, the depth 3.0-3.3 in SL; head length 4.354.7 in SL; caudal-peduncle absent; eye diameter 5.25-6.9 in HL; least vertical interorbital width 9.913.5 in HL; scales of body of adults with 8-14 cteni (mostly 10 or 11); longest dorsal ray 1.85-2.1 in HL; caudal fin $4.0-4.4$ in SL; origin of pelvic fins adjacent on ventral edge of body, the fins attached posteriorly to base of anal papilla; pelvic fins short, just reaching origin of anal fin, 2.7-3.3 in HL; ocular side finely mottled grey-brown to brown, with three longitudinal rows of dark brown spots of eye size or smaller (spots may be within larger pigmented blotches, the three largest on lateral line); dorsal and anal fins dusky yellowish with elongate dark spots paralleling rays; caudal fin pale yellowish with numerous small dark spots. Largest specimen, the holotype, $71.6 \mathrm{~mm} \mathrm{SL}$.

\section{Description}

Dorsal rays $72(65-74)$, anal rays $53(50-57)$, dorsal and anal rays branched at tips except anterior rays (first 14 dorsal rays and first 4 anal rays of holotype 


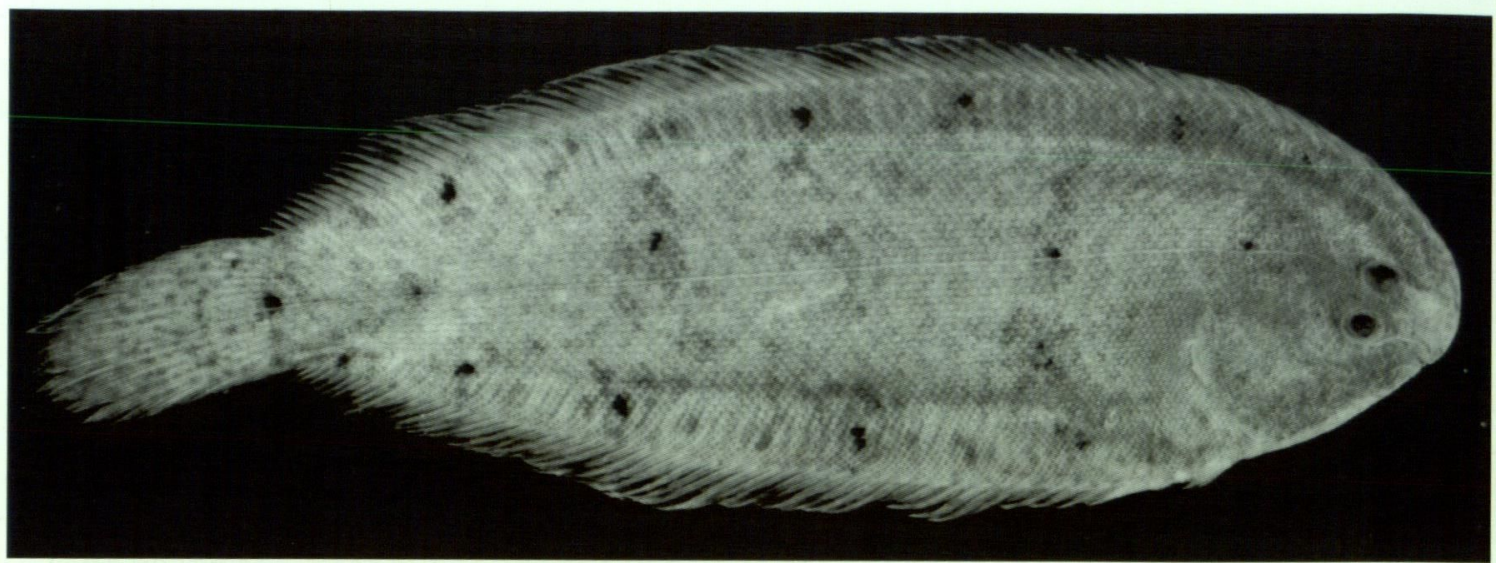

Figure 5 Holotype of Leptachirus kikori sp. nov., WAM P.31210-002, 71.6 mm SL, Kikori River, Papua New Guinea.

unbranched); caudal rays 18, 13 (13-14) branched in adults, 12 (10-12) of these double-branched in adults (none double-branched in small juveniles); pelvic rays 4 , none branched; lateral-line scales on ocular side 86 (76-88), including 9 (8-10) between a vertical at upper and of gill opening and ventral branch of lateral line on head; pores of ventral branch 7 (5-8); pores anterior to ventral branch 5 (3-5); scales above lateral line on ocular side about 31 , including 1-2 on base of dorsal fin; scales below lateral line about 40 , including 1-2 on base of anal fin; vertebrae $10+30(10+29-30)$; only erisma before tip of second neural spine; space between second and third neural spines with 5 (5) pterygiophores; space between third and fourth neural spines with 3 (3) pterygiophores, hence a total of 9 (two with 8, and five with 9) dorsal pterygiophores anterior to fourth neural spine. Ventroanterior margin of urohyal forming an angle of about $85^{\circ}\left(80-90^{\circ}\right)$, the inner angle moderately to strongly rounded.

Body slender, the depth 3.3 (3.0-3.1) in SL; body thin, the width 4.65 (4.1-5.75) in body depth; head length 4.7 (4.35-4.6) in SL; caudal peduncle absent; caudal-peduncle depth 1.8 (1.65-1.85) in HL; snout not overlapping or projecting anterior to lower lip when mouth closed (except on juveniles); snout length 2.8 (2.8-3.0) in HL; preorbital length 3.4 (3.15-3.6) in HL; eyes small, the eye diameter 6.9 (5.25-6.5) in HL; eyes close together, the least vertical interorbital width 13.4 (9.9-13.5) in HL; upper eye overlapping one-third (one-tenth to three-fourths) of lower eye; a horizontal line projected anteriorly from upper end of gill opening passing through ventral edge of lower eye.

Mouth inferior, the jaws strongly curved; maxilla reaching a vertical at anterior edge of pupil of lower eye, the upper-jaw length 3.25 (2.75-3.3) in HL; dense curved band of villiform teeth on blind side of both jaws, broadest centrally; tubular anterior nostril at edge of upper jaw in front of dorsal part of lower eye, not reaching cutaneous edge of eye when laid back, shorter than diameter of its base, and tapering little except basally; posterior nostril an oblique slit in labial groove covered by skin anterior to base of lower eye; anterior nostril of blind side a strongly tapering fleshy tubule in depression above upper lip nearly one-half distance to end of upper jaw, the length shorter than diameter of base; posterior nostril of blind side a tapering flat tubule nearly one-half eye diameter in length, dorsoposterior to anterior nostril, the internarial distance equal to cutaneous diameter of lower eye.

Scales ctenoid on both sides, with 7-11 cteni (mostly 9 or 10 on ocular side of body of holotype; usually 6 or 7 on juveniles); scales on ocular side of snout small, fleshy, with rudimentary cteni, extending to above front edge of anterior nostril; snout before anterior nostril and below level of dorsal edge of upper eye covered with thick smooth translucent tissue; a few dark brown cirri, mainly in rows, within this tissue; scales on blind side of head progressively smaller, with few cteni extending anteriorly on dorsal side a short distance before posterior nostril, and replaced anteriorly and over operculum by cirri and sensory papillae; eyes separated by 2 or 3 rows of scales, with 3-4 rows of small scales extending onto medial edges of eyes; no series of cirri along anterior edge of snout or ventral edge of head; short slender cirri on blind side of snout and ventral side of head nearly to edge; a series of about 20 small cirri along opercular edge of gill opening of blind side, but at most one or two ventrally on ocular side.

Lateral line straight on both sides along middle of body, with a short ventral preopercular branch on head of ocular side, the straight anterior part projecting toward upper eye; a cephalodorsal sensory line on ocular side submarginal to front of snout, passing posteriorly at base of dorsal fin and indistinctly onto anterior body; lateral line extending with pores into caudal fin along dorsal edge of tenth ray about three-fourths distance to posterior fin margin; cephalic sensory system of blind side as described for genus, with about 17 
temporal commissures (sensory lines alternating with bands of cirri) linking dorsal cephalic branch of lateral line with cephalodorsal line along base of dorsal fin.

Basal sheath of two or three rows of small scales on dorsal and anal fins; base of caudal fin with progressively smaller scales extending about threefourths distance to margin of fin, those more than half way as tiny scales, still with a few cteni, along edge of rays; dorsal and anal fins on both sides with a fleshy membranous ridge, better developed on blind side, extending more than half way to ray tips; ridges progressively narrower posteriorly and disappearing on last rays; no cirri on edge of ridges; ridges of ocular side with very small scales, but none on blind side; distal ends of anterior dorsal rays not filamentous.

Origin of dorsal fin anterior to ventral edge of upper eye, the predorsal length $3.3(3.2-3.8)$ in $\mathrm{HL}$; first dorsal ray $3.9(3.4-3.8)$ in $\mathrm{HL}$; longest dorsal ray $1.95(1.85-2.1)$ in $\mathrm{HL}$; origin of anal fin below base of sixteenth dorsal ray, the preanal length 4.35 (4.05-4.3) in SL; first anal ray 3.8 (2.9-4.15) in HL; longest anal ray $1.8(1.85-2.05)$ in head $\mathrm{HL}$; anus anterior to first anal ray; genital papilla at base of first anal ray, dorsoposterior to anus; caudal fin 4.4 $(4.0-4.3)$ in SL; origins of pelvic fins adjacent on ventral edge of body, the fins not diverging posteriorly, the last ray of each fin ending at anterior base of anal papilla; pelvic fins short, the third pelvic ray longest, just reaching origin of anal fin, $2.7(2.8-3.3)$ in HL.
Colour of ocular side of holotype in alcohol finely mottled grey-brown, with three longitudinal rows of dark brown spots smaller than eye: one of eight spots (two as double spots) below base of dorsal fin, one of five spots above base of anal fin (with a few fainter spots between), and one of five spots along lateral line (the third spot displaced above the line, the last at caudal-fin base); lateral-line spots within faint large dark blotches; dorsal and anal fins dusky yellowish with elongate dark brown spots paralleling rays, mainly in outer two-thirds of fin and involving two to four rays, but pigment mainly on membranes; caudal fin pale yellowish with many small brown spots, mainly on rays; pelvic fins pale dusky yellowish; blind side of body yellowish white. Paratypes from Waimake Creek collection darker brown on ocular side, the three rows of small dark brown spots more clearly within larger dark blotches.

\section{Etymology}

The new species name kikori is from the type locality, the Kikori River of southern Papua New Guinea. The name is treated as a noun in apposition.

\section{Remarks}

The specimens of Leptachirus kikori were collected from slightly brackish water at two collection sites of the Kikori River (Gerald R. Allen, pers. comm.).

Table 8 Proportional measurements of type specimens of Leptachirus kikori as percentages of the standard length.

\begin{tabular}{|c|c|c|c|c|c|c|c|}
\hline & \multirow{2}{*}{$\begin{array}{c}\text { Holotype } \\
\text { WAM } \\
\text { P.31210 }\end{array}$} & \multicolumn{6}{|c|}{ Paratypes } \\
\hline & & $\begin{array}{c}\text { WAM } \\
\text { P.30977 }\end{array}$ & $\begin{array}{c}\text { WAM } \\
\text { P.30977 }\end{array}$ & $\begin{array}{c}\text { WAM } \\
\text { P.30977 }\end{array}$ & $\begin{array}{c}\text { WAM } \\
\text { P.30977 }\end{array}$ & $\begin{array}{c}\text { WAM } \\
\text { P.30977 }\end{array}$ & $\begin{array}{c}\text { WAM } \\
\text { P.30977 }\end{array}$ \\
\hline Standard length (mm) & 71.6 & 38.2 & 43.7 & 48.9 & 52.9 & 57.0 & 58.4 \\
\hline Body depth & 30.3 & 33.2 & 32.0 & 33.0 & 32.2 & 32.9 & 32.3 \\
\hline Body width & 6.5 & 5.8 & 7.2 & 8.0 & 5.9 & 6.6 & 6.8 \\
\hline Head length & 21.4 & 23.0 & 22.8 & 22.3 & 22.9 & 22.9 & 21.9 \\
\hline Snout length & 7.6 & 7.9 & 7.8 & 7.9 & 7.7 & 7.6 & 7.7 \\
\hline Preorbital length & 6.3 & 6.8 & 6.9 & 7.1 & 6.4 & 6.4 & 6.3 \\
\hline Eye diameter & 3.1 & 4.3 & 3.5 & 4.0 & 3.6 & 3.7 & 3.4 \\
\hline Interorbital width & 1.6 & 2.1 & 2.3 & 2.0 & 1.9 & 1.7 & 1.7 \\
\hline Upper-jaw length & 6.6 & 7.0 & 7.2 & 7.9 & 7.6 & 7.5 & 7.9 \\
\hline Caudal-peduncle depth & 11.8 & 14.0 & 12.3 & 13.2 & 12.8 & 12.2 & 12.8 \\
\hline Caudal-peduncle length & 0.1 & 0.1 & 0.1 & 0.1 & 0.2 & 0.2 & 0.2 \\
\hline Predorsal length & 6.5 & 6.0 & 6.1 & 5.9 & 6.1 & 6.7 & 6.8 \\
\hline Preanal length & 23.0 & 24.6 & 23.2 & 24.5 & 24.1 & 24.0 & 23.6 \\
\hline Prepelvic length & 17.5 & 17.6 & 18.3 & 20.0 & 19.8 & 19.8 & 18.9 \\
\hline First dorsal ray & 5.5 & 6.1 & 6.6 & 6.5 & 6.8 & 6.0 & 6.4 \\
\hline Longest dorsal ray & 11.0 & 12.4 & 12.1 & 11.2 & 11.6 & 11.4 & 10.4 \\
\hline First anal ray & 5.6 & 6.8 & 5.5 & 6.6 & 5.7 & 6.7 & 7.5 \\
\hline Longest anal ray & 11.8 & 12.3 & 11.9 & 11.6 & 11.9 & 12.0 & 10.7 \\
\hline Caudal-fin length & 22.7 & 24.9 & 23.8 & 24.5 & 23.3 & 24.3 & 24.2 \\
\hline Pelvic-fin length & 8.0 & 7.0 & 8.2 & 8.0 & 7.7 & 7.2 & 7.0 \\
\hline
\end{tabular}

The full museum number for the holotype is WAM P.31210-002; for the six paratypes, WAM P.30977-020. 
Based on the number of dorsal and anal rays, broadly overlapping lateral-line scale counts, and most proportional measurements, this species seems most similar to $L$. alleni. The two differ mainly in the greater body depth of L. alleni, lack of a caudal peduncle (present, though extremely short in kikori), and 37-39 vertebrae (39-40 for kikori). Dorsal and anal fin rays and lateral-line scales were not counted on the three smallest paratypes.

\section{Leptachirus klunzingeri (Weber), comb. nov.} Figure 6

Pardachirus klunzingeri Weber, 1907: 250, pl. 13, fig. 2 (mouth of Merauke River, New Guinea).

\section{Remarks}

Weber described this species from a specimen 105 $\mathrm{mm}$ in total length, which is no longer extant at the Zoologisch Museum in Amsterdam. Although the date of his publication on the journal is given as 1908 , separates of the same paper were published in 1907. Weber regarded specimens identified as Solea thepassii (Bleeker) by Günther (1862: 478) to be his new species, Pardachirus klunzingeri. Achirus thepassii Bleeker from Ambon, Molucca Islands is now regarded as a synonym of Pardachirus poropterus (Bleeker) (Clark and George, 1979; Randall and Johnson, in press). Weber gave only a range in fin-ray and scale counts for $P$. klunzingeri: D 67-70. A 52-55. 1.1. 80-85. The meristic data for his holotype from the Merauke River is presumably within these ranges. Weber's illustration of klunzingeri therefore serves essentially as his description.

Weber (1913: 588) identified specimens from the Lorentz River on the south coast of New Guinea about $450 \mathrm{~km}$ northwest of the mouth of the Merauke River as Aseraggodes klunzingeri. Three lots of these specimens were located: ZMA 109399, BMNH 1913.12.15.38-39, and MNHN 59.592. None of these specimens match Weber's figure of klunzingeri. They are described below as a new species (the MNHN specimens are not considered as paratypes due to poor condition).
Leptachirus klunzingeri is not included in the above key to the species of the genus because diagnostic characters are lacking in Weber's description. Material should be sought from the Merauke River so that a neotype can be described.

\section{Leptachirus lorentz sp. nov.}

Figure 7; Tables 1-4, 9

Aseraggodes Klunzingeri (non Weber, 1908) Weber, 1913: 588 (Lorentz River, New Guinea).

\section{Holotype}

ZMA 109399, male?, $71.5 \mathrm{~mm}$, Indonesia, New Guinea, Papua Province, Lorentz River, Dr. Koch, no date of collection.

\section{Paratypes}

ZMA 123605-08, 4: 54.0-78.0 mm; BPBM 40460, 80.8 mm; USNM 387648, 57.4 mm; WAM P.32818$001,74.0 \mathrm{~mm}$, originally registered together with holotype and having same data; BMNH 1913.12.15.38-39, 2: 68.1-68.2 mm, Lorentz River, Bivak Island, 1907-1910.

\section{Nontype specimens}

MNHN 59.592, 2: 74-83 mm, presumed same data as holotype.

\section{Diagnosis}

Dorsal rays 68-78; anal rays 54-58; pelvic rays 4; lateral line on ocular side of head with a ventral branch of 4-6 pored scales, the remaining horizontal anterior part with 5-8 pored scales; lateral-line scales to point of branching on head 84-90, including 8-10 anterior to upper end of gill opening; vertebrae 40-42; dorsal pterygiophores anterior to fourth neural spine 8-9 (usually 9); body slender, the depth 3.25-3.5 in SL; head length 4.254.5 in SL; caudal-peduncle length 0 to 22.5 in HL; eye diameter 5.7-7.0 in HL; least vertical interorbital width 12.6-16.8 in HL; longest dorsal ray 2.05-2.2 in HL; caudal fin 4.25-4.6 in SL; origin of pelvic fins adjacent on ventral edge of body, the fins attached

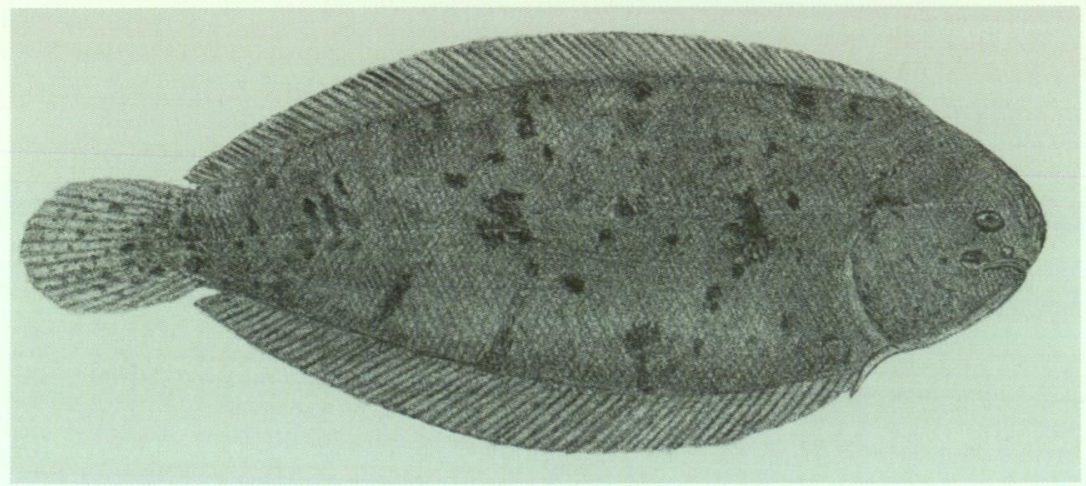

Figure 6 Holotype of Leptachirus klunzingeri, (after Weber, 1908), 105 mm TL, ZMA specimen not found. 


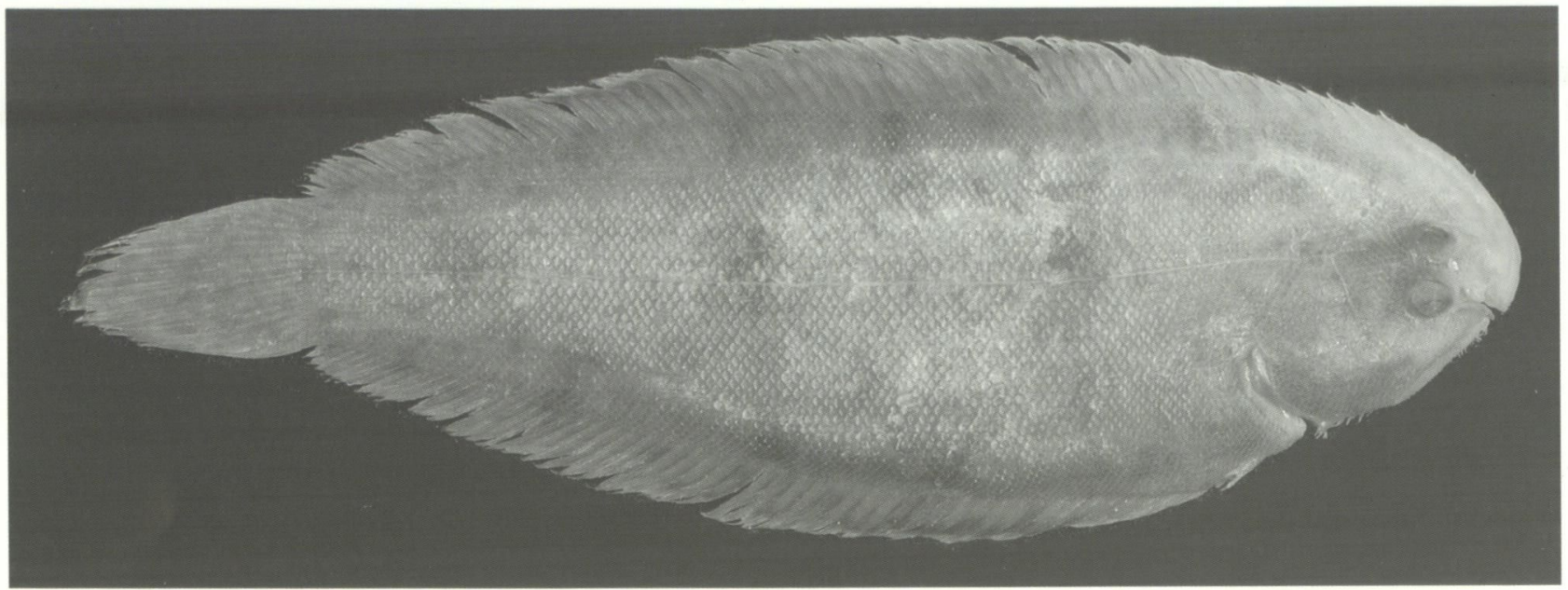

Figure 7 Holotype of Leptachirus lorentz sp. nov., ZMA 109399, 71.5 mm SL, Lorentz River, New Guinea.

posteriorly to base of anal papilla; pelvic fins short, not or just reaching origin of anal fin, 3.05-3.8 in HL; ocular side brown, mottled with small darker brown blotches; three longitudinal rows of larger dark brown blotches, the two largest on lateral line; dorsal and anal fins light brown with darker brown spots, most covering two rays; caudal fin with faint dark spots. Largest specimen, $80.8 \mathrm{~mm}$ SL.

\section{Description}

Dorsal rays 78 (68-76), anal rays 57 (54-58), dorsal and anal rays branched distally except anterior rays (first 14 dorsal rays and first 4 anal rays of holotype unbranched); pelvic rays 4 (one branched in two largest paratypes); lateral-line scales on ocular side 89 (84-90), including 9 (8-10) between a vertical at upper and of gill opening and ventral branch of lateral line on head; pored scales before ventral branch 6 (4-6); pored scales of ventral branch 7 (58 ); scales above lateral line on ocular side about 26 , including 3-4 on base of dorsal fin; scales below lateral line about 35 , including $1-2$ on base of anal fin; vertebrae $10+32(10+30-32)$; only erisma before tip of second neural spine; space between second and third neural spines with 6 (5) pterygiophores; space between third and fourth neural spines with $2(2-3)$ pterygiophores, hence a total of 9 (two with 8, and five with 9) dorsal pterygiophores anterior to fourth neural spine. Ventroanterior margin of urohyal forming an angle of about $85^{\circ}\left(80-105^{\circ}\right)$, the inner angle slightly to strongly rounded.

Body slender, the depth 3.5 (3.25-3.4) in SL; body thin, the width 4.1 (4.05-4.35) in body depth; HL 4.4 (4.25-4.5) in SL; caudal peduncle absent to extremely short, the greatest length 22.5 in HL; caudal-peduncle depth 1.8 (1.8-2.0) in HL; snout not overlapping or projecting anterior to lower lip when mouth closed; snout length 2.9 (2.95-3.3) in HL; preorbital length 3.25 (3.0-3.6) in HL; eyes small, the eye diameter 6.1 (5.7-7.0) in HL; eyes close together, the least vertical interorbital width 13.3 (12.6-16.8) in HL; upper eye overlapping threefourths (one-third to three-fourths) of lower eye; a horizontal line projected anteriorly from upper end of gill opening passing more than one eye diameter below lower eye.

Mouth inferior, the jaws strongly curved; maxilla reaching a vertical through centre of lower eye, the upper-jaw length 3.25 (3.2-3.45) in HL; a dense curved band of villiform teeth on blind side of both jaws, broadest centrally; tubular anterior nostril at edge of upper jaw in front of dorsal part of lower eye, not reaching cutaneous edge of eye when laid back, only slightly longer than diameter of its base, and tapering little; posterior nostril an oblique slit in labial groove covered by skin anterior to base of lower eye; anterior nostril of blind side a strongly tapering fleshy tubule in a depression above upper lip one-half distance to end of upper jaw, its length shorter than diameter of base; posterior nostril of blind side a tapering flat tubule about one-third eye diameter in length, dorsoposterior to anterior nostril, the internarial distance equal to diameter of eye.

Scales ctenoid on both sides, with 8-14 (mostly 10 or 11) cteni; scales on ocular side of snout small, fleshy, with rudimentary cteni, extending to above front edge of anterior nostril; snout before anterior nostril and below dorsal edge of upper eye naked; a small sensory tubule usually visible at level of ventral edge of upper eye, vertically above front edge of anterior nostril; scales on blind side of head with short cteni, extending anteriorly on dorsal side to posterior nostril, and replaced anteriorly and over operculum by cirri and sensory papillae; eyes separated by 1 or 2 rows of scales, with $2-3$ rows of smaller scales extending onto medial edges of eyes; no series of cirri along anterior edge of snout or ventral edge of head; short slender cirri present on 
blind side of snout and ventral side of head nearly to edge; a series of about 20 small cirri along opercular edge of gill opening of blind side, but none on ocular side.

Lateral line straight on both sides along middle of body, with a short ventral preopercular branch on head of ocular side, the straight anterior part projecting toward upper eye; a cephalodorsal sensory line on ocular side submarginal to front of snout, passing posteriorly at base of dorsal fin and becoming indistinct on anterior body; lateral line extending with pores into caudal fin along dorsal edge of tenth ray three-fourths distance to posterior fin margin; sensory pores and cirri forming three longitudinal bands on blind side of head dorsal to jaws, with 13 temporal commissures of low sensory papillae and cirri linking middle and cephalodorsal longitudinal sensory bands, the latter continuing indistinctly onto anterior third of body; preopercular sensory branch extending to lateral line where the latter forms two anterior branches of sensory papillae, and continuous with a row of cirri extending to cephalodorsal line; mandibuloopercular branch to upper end of gill opening with transverse branches of papillae and cirri connecting to preopercular branch on ventral part of operculum; a sensory line connecting preopercular branch to posterior end of upper jaw; transverse rows of papillae and cirri extending vertically from this branch to preopercular branch.

Basal sheath of three or four rows of small scales on dorsal and anal fins; base of caudal fin with progressively smaller scales extending about threefourths distance to margin of fin; dorsal and anal fins of ocular side with very small scales extending out on rays; dorsal and anal rays of blind side with a thin membranous ridge extending more than half way to ray tips, less developed posteriorly; no cirri on edges of membranous ridges; distal ends of anterior dorsal rays not filamentous.

Origin of dorsal fin (base of first ray) anterior to ventral edge of upper eye, the predorsal length 5.4 (4.6-5.55) in HL; first dorsal ray 3.2 (3.05-3.8) in $\mathrm{HL}$; longest dorsal ray 2.15 (2.05-2.2) in HL; origin of anal fin below base of eighteenth dorsal ray, the preanal length 3.95 (3.9-4.3) in SL; first anal ray 3.55 (3.3-3.7) in HL; longest anal ray $2.1(2.0-2.1)$ in HL; anus anterior to first anal ray; genital papilla at base of first anal ray, dorsoposterior to anus; caudal fin 4.4 (4.15-4.6) in SL; origins of pelvic fins adjacent on ventral edge of body, the fins not diverging posteriorly, the last ray of each fin ending at anterior base of anal papilla; pelvic fins very short, the second and third pelvic rays longest, not or just reaching origin of anal fin, 3.15 (3.05-3.8) in HL.

Colour of ocular side of holotype in alcohol brown, mottled with small darker brown blotches, and three longitudinal rows of larger dark brown blotches, one of seven blotches as large or larger than eye below base of dorsal fin, one of five above base of anal fin, and five along lateral line, the second and third the largest and most irregular; dorsal and anal fins brown with indistinct, elongate, darker brown spots from dark brown sections of

Table 9 Proportional measurements of type specimens of Leptachirus lorentz as percentages of the standard length.

\begin{tabular}{|c|c|c|c|c|c|c|c|}
\hline & \multirow{2}{*}{$\begin{array}{c}\text { Holotype } \\
\text { ZMA } \\
109399\end{array}$} & \multicolumn{6}{|c|}{ Paratypes } \\
\hline & & $\begin{array}{c}\text { ZMA } \\
123605\end{array}$ & $\begin{array}{l}\text { USNM } \\
\mathbf{3 8 7 6 4 8}\end{array}$ & $\begin{array}{c}\text { ZMA } \\
123606\end{array}$ & $\begin{array}{c}\text { ZMA } \\
123607\end{array}$ & $\begin{array}{c}\text { WAM } \\
\text { P.32818 }\end{array}$ & $\begin{array}{c}\text { BPBM } \\
40460\end{array}$ \\
\hline Standard length $(\mathrm{mm})$ & 71.5 & 54.0 & 57.4 & 61.3 & 70.1 & 74.0 & 80.8 \\
\hline Body depth & 28.8 & 29.3 & 30.8 & 29.4 & 29.9 & 29.4 & 30.7 \\
\hline Body width & 7.7 & 7.2 & 7.4 & 6.6 & 6.9 & 6.8 & 7.5 \\
\hline Head length & 22.6 & 22.7 & 22.2 & 22.9 & 23.0 & 23.6 & 23.4 \\
\hline Snout length & 7.8 & 6.6 & 7.5 & 6.9 & 7.1 & 7.4 & 7.5 \\
\hline Preorbital length & 7.0 & 6.4 & 7.4 & 6.5 & 6.4 & 6.7 & 7.1 \\
\hline Eye diameter & 3.7 & 4.0 & 3.5 & 4.0 & 3.3 & 3.4 & 3.7 \\
\hline Interorbital width & 1.7 & 1.8 & 1.6 & 1.8 & 1.5 & 1.4 & 1.5 \\
\hline Upper-jaw length & 7.0 & 6.6 & 7.0 & 6.4 & 6.8 & 6.8 & 7.4 \\
\hline Caudal-peduncle depth & 12.5 & 12.7 & 12.4 & 11.8 & 11.6 & 13.1 & 13.0 \\
\hline Caudal-peduncle length & 0.1 & 0.1 & 0.1 & 0.1 & 0.1 & 0 & 0.1 \\
\hline Predorsal length & 4.2 & 4.2 & 4.0 & 4.7 & 4.6 & 5.0 & 5.1 \\
\hline Preanal length & 25.2 & 23.4 & 25.5 & 23.2 & 23.6 & 24.9 & 25.7 \\
\hline Prepelvic length & 20.9 & 19.6 & 19.4 & 18.3 & 18.8 & 18.7 & 21.0 \\
\hline First dorsal ray & 7.1 & 7.3 & 7.3 & 6.4 & 7.0 & 6.2 & 6.5 \\
\hline Longest dorsal ray & 10.5 & 10.2 & 10.7 & 10.6 & 11.2 & 10.9 & 11.5 \\
\hline First anal ray & 6.4 & 6.8 & 6.7 & 6.6 & 6.7 & 6.5 & 6.3 \\
\hline Longest anal ray & 10.9 & 10.7 & 10.9 & 10.8 & 11.3 & 11.5 & 11.7 \\
\hline Caudal-fin length & 22.6 & 23.5 & broken & broken & 21.6 & 23.0 & broken \\
\hline Pelvic-fin length & 7.2 & 7.4 & 7.0 & 6.4 & 6.0 & 7.7 & 6.9 \\
\hline
\end{tabular}

The full museum number for the Western Australian Museum paratype is WAM P.32818-001. 
one or two rays and adjacent membranes; about anterior fourth of dorsal fin paler than remainder of fin and with only two faint dark spots; caudal fin with faint dark spots, more apparent basally; pelvic fins pale; blind side of body light brown.

\section{Etymology}

This species is named for the Lorentz River in the Timika area of the Papua Province of southern New Guinea, presently the only known locality. The species name is treated as a noun in apposition.

\section{Remarks}

As mentioned in the preceding account, the specimens of this species were first identified by Weber (1913) as Aseraggodes klunzingeri (Weber). Although the holotype of A. klunzingeri is lost, it is readily apparent from Weber's illustration (reproduced here as Figure 5) that it had a deeper body (2.7 in SL, compared to 3.25-3.5 for Leptachirus lorentz), a broader interorbital space, and a different colour pattern, so the two are clearly not conspecific.

The Natural History Museum in London has two specimens of this species (listed above as paratypes) that were a gift from the Zoologisch Museum, Amsterdam. The ZMA label with the specimens gives the locality as Bivak Island, Lorentz River. No date of collection or name of collector were given. Weber (1913) listed 34 specimens, 35-108 mm, from this locality and gave three different collection dates from 1907-1910. James Maclaine kindly provided photographs and $\mathrm{x}$-rays of both BMNH specimens, so fin-ray and vertebral counts have been included in the Tables 1-4.

The Muséum National d'Histoire Naturelle in Paris has two specimens of this species, MNHN 59.592, 2: 74-83 mm, also a gift from the Zoologisch Museum in Amsterdam. Unfortunately, these specimens had once been allowed to dry completely, so they could not be used for accurate fin-ray and scale counts and measurements. They are not designated as paratypes, but they were used for vertebral counts.

Leptachirus lorentz has the most slender body of the species of the genus but overlaps slightly in body depth with $L$. bensbach and $L$. kikori. It is separated from these two species by its higher vertebral counts of 40-42, compared to 39-40 (Table 4 ). There is complete separation from $L$. bensbach on eye size, $3.3-4.0 \%$ SL for L. lorentz compared to $2.7-3.0 \%$ for $L$. bensbach, and L. lorentz has distinctly higher average number of lateral-line scales than L. kikori (Table 3).

\section{Leptachirus polylepis sp. nov.}

Figure 8; Tables 1-4, 10

\section{Holotype}

NTM S.14083-007, male, 58.9 mm, Australia, Northern Territory, East Alligator River, Cannon Hill Lagoon, $12^{\circ} 22.0^{\prime} \mathrm{S}, 132^{\circ} 57.2^{\prime} \mathrm{E}, 1-4 \mathrm{~m}$, S.H. Midgley, 19 June 1973.

\section{Paratypes}

NTM S.14083-013, 5: 49.6-62.8 mm, BPBM 40461, 2: 53.5-58.6 mm, USNM 387208, 2: 48.0-52.9 mm, WAM P.32819-001, 2: 51.4-58.0 mm, and ZMB 33743, $52.4 \mathrm{~mm}$, same data as holotype; WAM P.25895-002, 54.0 mm, Australia, Northern Territory, South Alligator River, Barramundi Creek, crossing on Jabira - Pine Creek Road, 13 $14^{\prime}$ S, $132^{\circ} 26^{\prime}$ E, seine, G.R. Allen, C. Allen and G. Evans, 26 September 1977; NTM S.14546-001, 3: 52.5-60.7 $\mathrm{mm}$, Australia, Northern Territory, Mary River, Shady Camp Barrage, $12^{\circ} 29.30^{\prime} \mathrm{S}, 131^{\circ} 43.20^{\prime} \mathrm{E}, 1 \mathrm{~m}$, Wendy Gains, 23 November 1995; NTM S.14476001, 2: 38.8-39.0 mm, Australia, Northern Territory, West Alligator River, $12^{\circ} 17.6^{\prime} \mathrm{S}, 132^{\circ} 15.2^{\prime} \mathrm{E}, 10 \mathrm{~m}$, R. Williams and P. Pickworth, 27 May 1997.

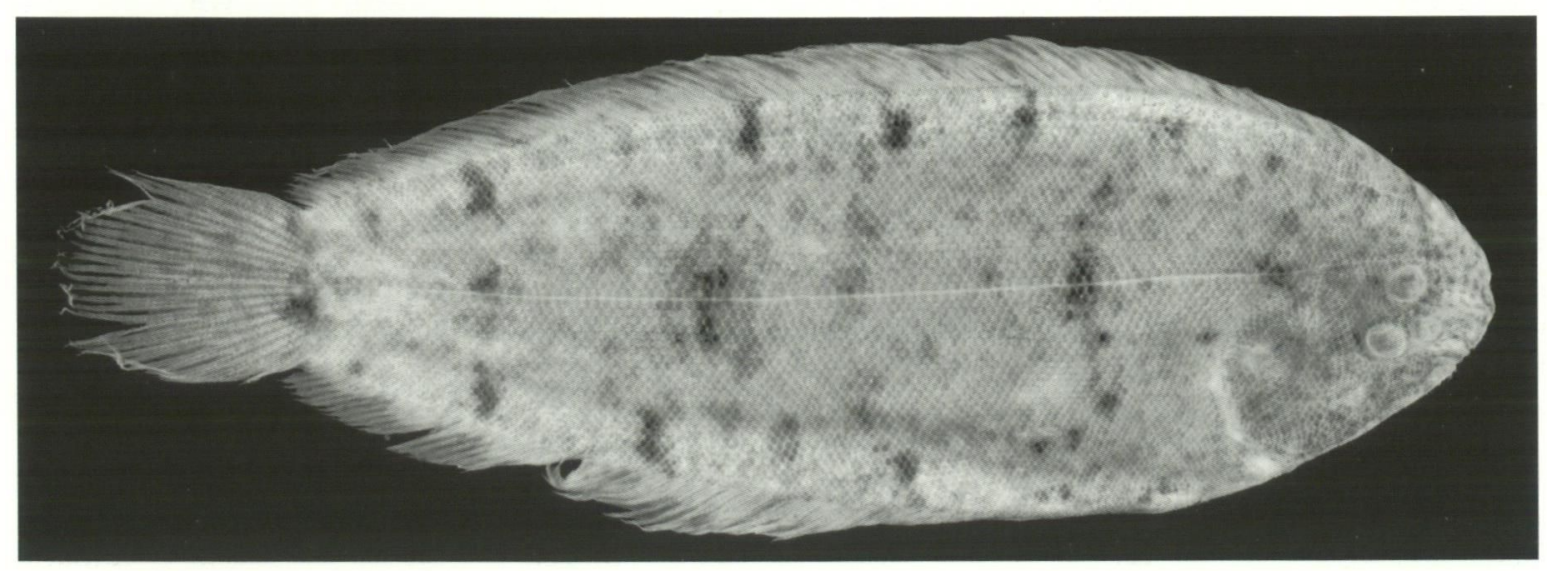

Figure 8 Holotype of Leptachirus polylepis sp. nov., NTM S.14083-007, 58.9 mm SL, East Alligator River, Northern Territory, Australia. 


\section{Diagnosis}

Dorsal rays 70-77; anal rays 54-58; pelvic rays 4 or 5 (usually 4); lateral-line scales 103-111; lateral line on ocular side of head with a ventral branch of 5 to 6 pores, the remaining horizontal anterior part with 3-4 pores; vertebrae 40-42; dorsal pterygiophores anterior to fourth neural spine 8-9 (usually 9); body depth 2.95-3.2 in SL; caudal peduncle absent; head length $4.45-4.65$ in SL; eye diameter 6.35-6.8 in HL; interorbital width 8.6-10.5 in HL; tubular anterior nostril short, only slightly longer than diameter of base, and tapering little; longest dorsal ray 1.8-2.15 in HL; caudal-fin length 4.15-4.7 in SL; pelvic fins not joined to genital papilla, their origins adjacent; pelvic fins short, reaching little beyond base of first anal ray, 2.7-3.1 in HL; colour of ocular side in alcohol brown, faintly mottled with small darker brown spots; three longitudinal rows of dark brown spots, most vertically elongate, the largest two on lateral line; dorsal and anal fins with dark brown streaks on two to four adjacent rays; caudal fin with dark brown blotches on base. Largest specimen, $62.8 \mathrm{~mm}$ SL.

\section{Description}

Dorsal rays 74 (70-77), anal rays 55 (54-58), dorsal and anal rays branched at tips except anterior rays (first 15 dorsal rays and first 2 anal rays of holotype unbranched); caudal rays 18, 14 (14-15) branched, $12(12-13)$ of these double-branched; pelvic rays 4 (ten paratypes with 4 rays in both fins, two with 5 rays in both fins; and five with 4 rays in one fin and 5 in the other); no pelvic rays branched; lateral-line scales on ocular side 109 (103-111), including 12 (11-13) between a vertical at upper end of gill opening and ventral branch of lateral line on head; pores of ventral branch 6 (5-6); pores in remaining horizontal anterior part of lateral line 4 (3-4) pores; lateral line extending into caudal fin along dorsal edge of tenth ray about three-fourths distance to posterior fin margin; scales above lateral line on ocular side of holotype 31 , below lateral line 42 , including those on base of fins; vertebrae $10+31(10$ $+30-32)=41(40-42)$; only erisma before tip of second neural spine; space between second and third neural spines with 6 (4-6) pterygiophores; space between third and fourth neural spines with 3 (2-3) pterygiophores, hence a total of $9(8-9)$ dorsal pterygiophores anterior to fourth neural spine. Ventroanterior margin of urohyal forming an angle of about $85^{\circ}\left(80-90^{\circ}\right)$, the inner angle moderately to strongly rounded.

Body slender, the depth 3.0 (2.95-3.2) in SL; body thin, the width (thickness) $4.0(4.1-4.65)$ in body depth; head length 4.45 (4.4-4.65) in SL; no caudal peduncle; depth of caudal-fin base $1.8(1.65-1.85)$ in $\mathrm{HL}$; snout not overlapping or projecting anterior to lower lip when mouth closed; snout length 3.0 (2.85-3.05) in HL; preorbital length 3.35 (3.15 -3.5) in $\mathrm{HL}$; eye diameter $6.8(6.3-6.7)$ in $\mathrm{HL}$; least vertical interorbital width $9.0(8.6-10.5)$ in $\mathrm{HL}$; upper eye overlapping one-third (one-fifth to onehalf) of lower eye; a horizontal line projected

Table 10 Proportional measurements of type specimens of Leptachirus polylepis as percentages of the standard length.

\begin{tabular}{lcrrrrrrr} 
& Holotype & & \multicolumn{3}{c}{ Paratypes } \\
& NTM & NTM & NTM & WAM & NTM & WAM & NTM & NTM \\
& S.14083 & S.14083 & S.14083 & P.32819 & S.14083 & P.3281 & S.14083 & S.14083 \\
\hline Standard length (mm) & 58.9 & 38.9 & 49.6 & 51.4 & 53.2 & 57.0 & 59.0 & 61.2 \\
Body depth & 33.3 & 31.5 & 32.5 & 33.1 & 33.4 & 31.8 & 32.4 & 31.2 \\
Body width & 8.3 & 7.5 & 7.0 & 7.8 & 7.7 & 7.2 & 7.7 & 7.6 \\
Head length & 22.5 & 22.6 & 22.2 & 22.4 & 22.1 & 22.2 & 22.0 & 21.4 \\
Snout length & 7.5 & 7.7 & 7.8 & 7.7 & 7.5 & 7.6 & 7.2 & 7.5 \\
Preorbital length & 6.7 & 7.2 & 7.0 & 7.0 & 6.8 & 6.9 & 6.3 & 6.3 \\
Eye diameter & 3.3 & 3.6 & 3.5 & 3.4 & 3.4 & 3.3 & 3.4 & 3.3 \\
Interorbital width & 2.5 & 2.3 & 2.4 & 2.5 & 2.1 & 2.1 & 2.3 & 2.6 \\
Upper-jaw length & 5.9 & 6.7 & 6.4 & 6.4 & 6.0 & 6.5 & 5.9 & 5.8 \\
Depth of caudal-fin base & 12.5 & 12.9 & 13.0 & 13.2 & 13.1 & 12.0 & 13.3 & 13.1 \\
Predorsal length & 6.0 & 5.6 & 6.0 & 5.9 & 5.9 & 5.5 & 6.2 & 5.9 \\
Preanal length & 24.9 & 23.1 & 23.4 & 25.0 & 23.2 & 23.2 & 24.6 & 23.2 \\
Prepelvic length & 19.2 & 18.8 & 19.3 & 19.4 & 18.3 & 17.9 & 18.7 & 18.2 \\
First dorsal ray & 6.4 & 6.4 & 6.3 & 5.4 & 5.9 & 5.7 & 5.5 & 6.5 \\
Longest dorsal ray & 11.4 & 12.5 & 12.2 & 11.5 & 11.2 & 10.8 & 10.2 & 11.1 \\
First anal ray & 6.0 & 5.9 & 6.2 & 6.3 & 6.6 & 6.7 & 6.5 & 6.3 \\
Longest anal ray & 11.5 & 12.9 & 12.5 & 11.7 & 11.4 & 10.9 & 10.5 & 11.3 \\
Caudal-fin length & 22.5 & 23.5 & 24.0 & 23.6 & 21.9 & 21.6 & 22.2 & 21.2 \\
Pelvic-fin length & 7.6 & 7.6 & 8.1 & 7.8 & 7.9 & 7.7 & 7.1 & 7.9 \\
\hline
\end{tabular}

The full museum number for the holotype is NTM S.14083-007, and for the five NTM paratypes, NTM S.14083-013. The full number for the two WAM paratypes is WAM P.32819-001. 
anteriorly from upper end of gill opening passing nearly one eye diameter below lower eye.

Mouth inferior, the jaws strongly curved; posterior corner of jaws reaching a vertical through anterior edge of pupil of lower eye, the upper-jaw length 3.8 (3.4-3.7) in HL; a dense curved band of villiform teeth on blind side of both jaws; tubular anterior nostril in slight depression at edge of upper jaw before dorsal edge of lower eyes, shorter than diameter of its base, and tapering slightly; posterior nostril an oblique slit in labial groove covered by skin anterior to base of lower eye; anterior nostril of blind side a strongly tapering tubule in a depression above upper jaw nearly one-half distance to end of upper jaw, its length shorter than diameter of its base; posterior nostril of blind side a flattened tapering tubule about half size of anterior nostril, dorsoposterior to anterior nostril, the internarial distance 1.3 times eye diameter.

Scales ctenoid on both sides, with 7-10 (usually 8 or 9) prominent cteni extending well beyond scale edge; scales on ocular side before eyes of snout small with about 3 cteni, replaced above anterior nostril by naked area with scattered brown cirri (more slender on Mary River specimens); scales on blind side of head becoming fleshy with short cteni anteriorly, and replaced by papillae before posterior end of jaws; eyes separated by $3(3-4)$ rows of scales, with 3-4 rows of smaller scales extending onto medial edges of eyes; no cirri directly on anterior edge of snout or ventral edge of head, but series of short slender cirri present on blind side nearly to edge; a series of about 20 slender short cirri along opercular edge of gill opening of blind side (difficult to see on some specimens without staining), but none on ocular side.

Lateral line straight on both sides along middle of body, with a short ventral preopercular branch on ocular side of head, and a short straight anterior part projecting toward upper eye; a faint pale line (evidently sensory, but with no obvious pores) from above the point of branching, passing forward just dorsal to upper eye, and ending a short distance before eye; a thin cephalodorsal sensory line on ocular side from front of snout, passing posteriorly below base of dorsal fin, and indistinctly onto anterior body; lateral line extending with pores into caudal fin along dorsal edge of tenth ray about three-fourths distance to posterior fin margin; lateral line on blind side dividing to two rows of sensory papillae at level of posterior edge of preopercle, diverging to front of snout; cephalodorsal branch of lateral line on blind side indistinct on about anterior half of body; zone between dorsal branch of lateral line and cephalodorsal branch crossed by about 20 temporal commissures of sensory papillae mixed with cirri; a broad mixed zone of papillae and cirri on ventral part of blind side of head, with a preopercular sensory branch extending to lateral line at branching point; about nine oblique sensory branches linking ventral part of mandibuloopercular and preopercular branches ventrally on head and continuing to lower part of mouth; a separate, less oblique transverse branch about twofifths distance to dorsal end of gill opening, and a sensory line connecting preopercular branch to corner of mouth.

Basal sheath of three or four rows of small scales on dorsal and anal fins; progressively smaller scales extending out rays and membranes of about basal half of caudal fin; tiny scales, still with cteni, continuing out on rays about two-thirds distance to posterior margin; dorsal and anal rays on both sides with a thin membranous ridge extending more than half way to ray tips, much broader on blind side, finely scaled on ocular side; no cirri on ridge edges; distal end of dorsal and anal rays as a short filament except for first few rays.

Origin of dorsal fin anterior to ventral third of upper eye, the predorsal length 3.7 (3.5-4.05) in $\mathrm{HL}$; first dorsal ray 3.5 (3.3-4.15) in HL; longest dorsal ray 1.95 (1.8-2.15) in HL; origin of anal fin below base of seventeenth dorsal ray, the preanal length 4.0 (4.0-4.35) in SL; first anal ray 3.75 (3.3$3.85)$ in $\mathrm{HL}$; longest anal ray $1.95(1.75-2.1)$ in $\mathrm{HL}$; anus anterior to first anal ray; genital papilla at base of first anal ray, dorsoposterior to anus; caudal fin $4.45(4.15-4.7)$ in SL; origins of pelvic fins adjacent; pelvic fins not diverging posteriorly, the last membrane of each fin ending at base of anal papilla; second pelvic ray longest, reaching to or slightly beyond base of first anal ray, 2.95 (2.7$3.1)$ in HL.

Colour of ocular side of holotype in alcohol brown, faintly mottled with small darker brown spots; three longitudinal rows of dark brown spots, most of which are vertically elongate: a row of seven spots on body below base of dorsal fin, the last small, with three small spots dorsally on head; a ventral row of seven spots above anal fin, the first two as groups of spots, and the last small; a row of seven spots along lateral line, the second and fourth largest; dorsal and anal fins pale yellowish, the rays brown, becoming pale distally; groups of two to four rays with a broad dark brown streak, mainly basally, some in alignment with dark brown spots on body; scaled basal part of caudal fin coloured like body with basal row of dark brown blotches, the largest centred below lateral line; rest of fin pale yellowish with faint dark spots; pelvic fins pale yellowish brown. Colour of blind side pale orangish brown, the head a little darker.

\section{Etymology}

This species is named polylepis from the Greek meaning many scales, in reference to its very high lateral-line scale count. 


\section{Remarks}

Leptachirus polylepis was collected from the East Alligator, South Alligator, West Alligator, Mary, and Adelaide Rivers in the Northern Territory of Australia, all of which empty into Van Diemen's Gulf to the east of Darwin. The holotype came from the Cannon Hill Lagoon of the East Alligator River; it is freshwater, but occasionally gets tidal input. Barramundi Creek of the South Alligator River, the locality for the $54 \mathrm{~mm}$ paratype, is freshwater. The remaining localities are estuarine or freshwater subject to tidal input (Helen K. Larson, pers. comm.).

The five paratypes of NTM S.14083-013 were removed from one lot of 195 specimens. The remaining 190 specimens, NTM S.14083-014, 40.7$63.8 \mathrm{~mm}$, are not designated as paratypes.

One other species of the genus, L. darwinensis, was also found in the East Alligator, South Alligator, and Adelaide Rivers. The two species are completely separated by lateral-line scale counts: 90-93 for L. darwinensis, compared to 103-111 for $L$. polylepis; also $L$. darwinensis has a lower average count of dorsal and anal rays, a slightly deeper body, and slightly longer median fins.

Gut material was noticed partially extruded from the anus of the $58.5-\mathrm{mm}$ specimen of $L$. polylepis from the East Alligator River. It proved to be the remains of hemipteran insects.

\section{Leptachirus robertsi sp. nov.}

Figure 9; Tables 1-4, 11

Aseraggodes klunzingeri (non Weber, 1988) Roberts, 1978: 69 (Fly River).

\section{Holotype}

USNM 217314, female, $65.0 \mathrm{~mm}$, Papua New Guinea, Western Province, tidal creek on right side of Lower Fly River, $1 \mathrm{~km}$ upriver from D'Albertis Island, $8^{\circ} 12^{\prime} 54^{\prime \prime} \mathrm{S}, 142^{\circ} 3^{\prime} 54^{\prime \prime} \mathrm{E}, 0-1.0 \mathrm{~m}$, rotenone, T.R. Roberts, 13 December 1975.

\section{Paratypes}

USNM 217313, 2: 32.2-35.0 mm, Papua New Guinea, Western Province, Lower Fly River, creek strongly influenced by tides, directly east of upriver end of Tidal Island, $236 \mathrm{~km}$ upriver from Toro Pass, $7^{\circ} 59^{\prime} 18^{\prime \prime} \mathrm{S}, 142^{\circ} 0^{\prime} 36^{\prime \prime} \mathrm{E}$, rotenone, T.R. Roberts, 11 December 1975; BMNH 2007.2.9.1, 30.6 mm, BPBM 40506, $52.7 \mathrm{~mm}$, NTM S.16389-001, $33.5 \mathrm{~mm}$, and USNM 389200, 12: 19.5-71 mm, all with same data as holotype; WAM P.28150-010, $34.5 \mathrm{~mm}$, Papua New Guinea, small turbid side branch of the Lower Fly River near Cassowary Island, about $260 \mathrm{~km}$ from the sea, $7^{\circ} 52^{\prime} \mathrm{S}, 141^{\circ} 50^{\prime} \mathrm{E}$, rotenone, G.R Allen and D. Balloch, 15 September 1983; WAM P. 28151006, 3: 22.5-34.3 mm, Papua New Guinea, small turbid slow-flowing creek, about $1 \mathrm{~km}$ from Burei
River (a tributary of the Lower Fly River), about 215 $\mathrm{km}$ from the sea, $8^{\circ} 12^{\prime} \mathrm{S}, 142^{\circ} 1^{\prime} \mathrm{E}$, rotenone, G.R. Allen and A. Maie, 16 September 1983.

\section{Diagnosis}

Dorsal rays 66-74; anal rays $50-57$; pelvic rays 4; lateral line on ocular side of head with a ventral branch of 5-7 pored scales, the remaining horizontal anterior part with 4-5 pored scales; lateral-line scales to point of branching on head 78-87, including 8-9 anterior to upper end of gill opening; vertebrae 38-40; dorsal pterygiophores anterior to fourth neural spine 8-9; body slender, the depth 3.0-3.15 in SL; head length 4.0-4.25 in SL; caudalpeduncle absent; eye diameter 5.7-8.1 in HL; least vertical interorbital width 11.2-26.0 in HL; scales of body of adults with 8-12 cteni (mostly 9 or 10 ); longest dorsal ray $1.8-2.15$ in HL; caudal fin $3.8-4.3$ in SL; origin of pelvic fins adjacent on ventral edge of body, the fins attached posteriorly to base of anal papilla; pelvic fins short, reaching base of first anal ray, 2.7-2.9 in HL; ocular side brown, finely mottled with darker brown, with three longitudinal rows of dark brown spots of eye size or smaller, one below dorsal fin, one above anal fin, and one along lateral line; dorsal and anal fins dusky yellowish the rays more heavily pigmented, some with sections in outer part still darker; basal scaled part of caudal fin coloured like body, the rest of fin pale yellowish with scattered faint small dark spots. Largest specimen, $71.4 \mathrm{~mm}$ SL.

\section{Description}

Dorsal rays 70 (66-74), anal rays $52(50-57)$, dorsal and anal rays of adults finely branched except a few anterior rays of dorsal fin; caudal rays 18,14 branched, and 12 double-branched in adults (none double-branched in small juveniles); pelvic rays 4 , none branched (except one anterior ray of $52.7-\mathrm{mm}$ paratype); lateral-line scales on ocular side 82 (7887 ), including 9 (8-9) between a vertical at upper end of gill opening and ventral branch of lateral line on head; pore scales of ventral branch 6 (5-7); pored scales anterior to ventral branch $5(4-5)$; scales above lateral line on ocular side about 30 , including 3-4 small scales on base of dorsal fin; scales below lateral line about 34 , including 3-4 small scales on base of anal fin; vertebrae $10+30(10$ $+28-29$ ); only erisma before tip of second neural spine; space between second and third neural spines with 5 pterygiophores; space between third and fourth neural spines with $2(2-3)$ pterygiophores, hence a total of 8 (8-9, usually 8 ) dorsal pterygiophores anterior to fourth neural spine, with erisma counted as 1 . Ventroanterior margin of urohyal forming an angle of about $80^{\circ}$ $\left(80-90^{\circ}\right)$, the inner angle moderately to strongly rounded.

Body slender, the depth $3.1(3.0-3.15)$ in SL; body 


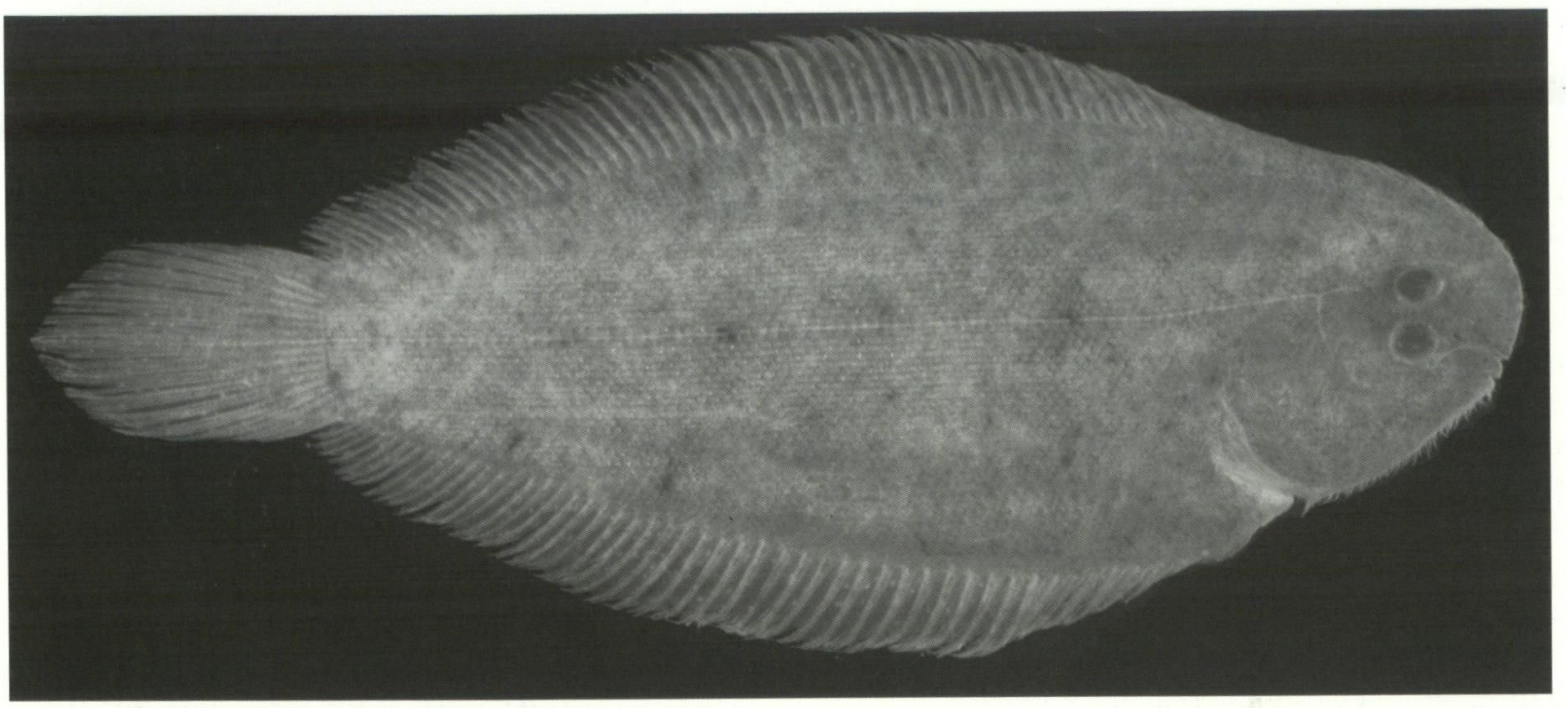

Figure 9 Holotype of Leptachirus robertsi sp. nov., USNM 217314, 65.0 mm SL, Fly River, Papua New Guinea.

thin, the width 4.2 (3.95-4.6) in body depth; head length 4.0 (4.15-4.25) in SL; caudal peduncle absent; caudal-peduncle depth 1.9 (1.8-2.0) in HL; snout not overlapping or projecting anterior to lower lip when mouth closed (except on juveniles); snout length 3.0 (2.75-2.95) in HL; preorbital length 2.65 (2.65-3.45) in HL; eyes small, the eye diameter 8.1 (5.7-7.7) in HL; eyes close together, the least vertical interorbital width 14.7 (11.2-26.0) in HL; upper eye overlapping two thirds (one-third to three-fourths) of lower eye; a horizontal line projected anteriorly from upper end of gill opening passing an eye diameter (one-half to one eye diameter) ventral to lower eye.
Mouth inferior, the jaws strongly curved; maxilla nearly or just reaching a vertical at anterior edge of pupil of lower eye, the upper-jaw length 2.95 (2.8 3.1) in HL; a dense curved band of villiform teeth on blind side of both jaws, broadest centrally; tubular anterior nostril at edge of upper jaw in front of dorsal part of lower eye, not reaching cutaneous edge of eye when laid back, and only slightly tapered; posterior nostril an oblique slit in labial groove covered by skin anterior to base of lower eye; anterior nostril of blind side a short tapering fleshy tubule a nostril diameter above upper jaw, nearly one-half distance to end of jaw; posterior nostril of blind side a tapering flat tubule nearly

Table 11 Proportional measurements of type specimens of Leptachirus robertsi as percentages of the standard length.

\begin{tabular}{|c|c|c|c|c|c|c|}
\hline & Holotype & & & Paratypes & & \\
\hline & USNM & BMNH & WAM & WAM & ВРBM & USNM \\
\hline & 217314 & 07.2 .9 .1 & P.28151 & P.28150 & 40506 & 389200 \\
\hline Standard length (mm) & 65.0 & 30.6 & 33.8 & 34.5 & 52.7 & 71.4 \\
\hline Body depth & 32.4 & 32.7 & 31.6 & 33.7 & 32.2 & 31.8 \\
\hline Body width & 7.7 & 7.5 & 8.0 & 7.3 & 7.8 & 7.6 \\
\hline Head length & 25.1 & 23.5 & 24.0 & 23.5 & 23.9 & 24.2 \\
\hline Snout length & 8.4 & 8.6 & 8.4 & 8.0 & 8.5 & 8.8 \\
\hline Preorbital length & 6.9 & 8.8 & 8.3 & 6.9 & 7.1 & 7.0 \\
\hline Eye diameter & 3.1 & 3.8 & 3.1 & 4.1 & 3.7 & 3.2 \\
\hline Interorbital width & 1.7 & 2.1 & 1.9 & 0.9 & 1.9 & 2.1 \\
\hline Upper-jaw length & 8.5 & 7.9 & 7.8 & 8.4 & 8.6 & 8.4 \\
\hline Caudal-peduncle depth & 13.1 & 13.1 & 11.9 & 12.2 & 12.2 & 12.8 \\
\hline Caudal-peduncle length & 0 & 0 & 0 & 0 & 0 & 0 \\
\hline Predorsal length & 7.1 & 6.4 & 6.4 & 6.1 & 7.3 & 7.0 \\
\hline Preanal length & 26.9 & 26.1 & 26.3 & 26.6 & 26.7 & 26.7 \\
\hline Prepelvic length & 21.7 & 19.6 & 21.0 & 20.5 & 19.9 & 21.1 \\
\hline First dorsal ray & 6.3 & 6.2 & 6.1 & 6.2 & 5.6 & 6.1 \\
\hline Longest dorsal ray & 11.8 & 12.9 & 13.0 & 12.6 & 11.4 & 11.3 \\
\hline First anal ray & 7.3 & 6.5 & 6.6 & 6.2 & 6.7 & 7.5 \\
\hline Longest anal ray & 12.2 & 13.0 & 13.2 & 12.9 & 12.3 & 11.4 \\
\hline Caudal-fin length & 25.0 & broken & 26.1 & 23.2 & 24.7 & 23.2 \\
\hline Pelvic-fin length & 8.6 & 8.3 & 8.5 & 8.7 & 8.8 & 8.4 \\
\hline
\end{tabular}


one-half eye diameter in length, dorsoposterior to anterior nostril, the internarial distance greater than diameter of lower eye.

Scales ctenoid on both sides, with 8-12 cteni (mostly 9 or 10 on ocular side of adults and $6-8$ on juveniles); scales on ocular side of snout small, fleshy, with rudimentary cteni, extending to above front edge of anterior nostril; snout before anterior nostril and below level of dorsal edge of upper eye covered with thick translucent tissue; scales on operculum of blind side of head of holotype with 5-10 cteni, becoming more fleshy and with fewer cteni anteriorly, and entirely as small papillae a short distance behind posterior end of jaws; eyes separated by 3 rows of scales, with a few rows of small scales extending onto medial and anterior edges of eyes; slender cirri anteriorly on blind side of snout and ventral side of head nearly to edge, the longest little more than pupil diameter; a series of short slender cirri along opercular edge of gill opening of blind side, but none on ocular side.

Lateral line straight on both sides along middle of body, with a short ventral preopercular branch on head of ocular side, the anterior part projecting toward upper eye; a cephalodorsal sensory line on ocular side submarginal to front of snout (where indistinct) passing posteriorly at base of dorsal fin and onto anterior body; lateral line extending with pores into caudal fin along dorsal edge of tenth ray about three-fourths distance to posterior fin margin; cephalic sensory system of blind side as described for genus, with about 16 temporal commissures (sensory lines alternating with bands of cirri, those anteriorly close together and difficult to count) linking dorsal cephalic branch of lateral line with cephalodorsal line along base of dorsal fin.

Basal sheath of three or four rows of small scales on dorsal and anal fins; base of caudal fin with progressively smaller scales extending about threefourths distance to margin of fin, those more than half way as tiny scales, still with a few cteni, along edge of rays; dorsal and anal fins on both sides with a fleshy membranous ridge, well developed on blind side, extending more than half way to ray tips, but disappearing on posterior rays; ridges present only on anterior rays of ocular side; no cirri on edge of ridges; ridges of ocular side with very small scales, but none on blind side; distal ends of anterior dorsal rays not filamentous.

Origin of dorsal fin anterior to ventral edge of upper eye, the predorsal length 3.55 (3.3-3.7) in HL; first dorsal ray $4.0(3.95-4.25)$ in HL; longest dorsal ray $2.1(1.8-2.15)$ in $\mathrm{HL}$; origin of anal fin below base of fifteenth dorsal ray, the preanal length 3.7 $(3.75-3.8)$ in SL; first anal ray $3.45(3.2-3.95)$ in $\mathrm{HL}$; longest anal ray $2.05(1.8-2.1)$ in HL; anus anterior to first anal ray; genital papilla at base of first anal ray, dorsoposterior to anus; caudal fin 4.0 (3.8-4.3) in SL; origins of pelvic fins adjacent on ventral edge of body, the fins not diverging posteriorly, the last ray of each fin ending at anterior base of anal papilla; pelvic fins short, the third pelvic ray longest, just reaching base of first anal ray, 3.1 (2.72.85) in HL.

Colour of ocular side of holotype in alcohol brown, finely mottled with darker brown; three longitudinal rows of dark brown spots smaller than eyes, one below base of dorsal fin, one above base of anal fin, and one on lateral line.; spots of periphral rows numerous, indistinct, and tending to be vertically elongate; row on lateral line with only three distinct spots; dorsal and anal fins pale dusky yellowish, the rays more heavily pigmented; basal two-fifths of caudal fin coloured like body, the rest of fin pale yellowish with scattered small brown spots on rays; colour of blind side pale tan without markings.

\section{Etymology}

This species is named for Tyson R. Roberts who collected the holotype and most of the paratypes.

\section{Remarks}

Leptachirus robertsi is presently known only from the Lower Fly River of Papua New Guinea and the Burei River, a tributary of the Lower Fly River. It was collected from small turbid creeks. Gerald R. Allen (pers. comm.) reported the following species of fishes that were obtained in the Lower Fly River with the $34.5 \mathrm{~mm}$ WAM paratype of $L$. robertsi: Nematalosa sp., Ambassis agrammus, Lutjanus goldiei, Toxotes chatareus, Glossogobius sp. Eleotris melanosoma, and Prionobutis microps. He collected the following fishes at the Burei River station with the three small WAM paratypes: Oligolepis acutipennis, Redigobius bikolanus, Taenioides cirratus, Eleotris fusca, Ophieleotris aporos, and Prionobutis microps.

Because of the similarity in colour pattern and meristic data, this species was first believed to be Leptachirus kikori. More careful comparison with the latter, however, revealed a larger head, longer snout, and larger jaws than in L. kikori. This species also lacks a caudal peduncle, although in L. kikori the caudal peduncle can be so short that it is difficult to measure. In addition, the fleshy ridges on the dorsal and anal rays of the ocular side of $L$. kikori are well developed except posteriorly, but weakly developed and only anteriorly on the rays of $L$. robertsi.

\section{Leptachirus triramus sp. nov.}

Figure 10; Tables 1-4, 12

\section{Holotype}

NTM S.11543-004, male, $39.6 \mathrm{~mm}$, Australia, Northern Territory, Victoria River, Wattie Creek, 
$17^{\circ} 24^{\prime}$ S, $130^{\circ} 52^{\prime} E, 0-2$ m, P. Horner, 13 November 1984.

\section{Paratypes}

NTM S.11543-009, $43.0 \mathrm{~mm}$, same data as holotype; WAM P.20608-001, 4: 42.3-59.1 mm, Western Australia, Ord River, Stockyard Pool, $16^{\circ} 20^{\prime}$ S, $128^{\circ} 50^{\prime}$ E, R.J. McKay et al., 4 October 1971; BPBM 40455, 2: 42.2-45.3 mm, USNM 387647, 2: 42.0-42.4 mm, and ZMB 33738, 2: $42.2-49.3 \mathrm{~mm}$, same data as WAM P.20608-001; WAM P. 30067007, 4: 44.5-52.0 mm, Ord River, $17^{\circ} 25^{\prime} \mathrm{S}, 1^{\circ} 48^{\circ} \mathrm{E}$, J. Woinarski, 21 November 1989; QM I.38113, 3: 28.4 $39.0 \mathrm{~mm}$, Northern Territory, Daly River crossing at concrete causeway, $13^{\circ} 46.2^{\prime} S, 130^{\circ} 42.5^{\prime} \mathrm{E}$, S. Hurley, 7 May 2007.

\section{Diagnosis}

Dorsal rays 65-72; anal rays 50-56; lateral-line scales 71-84; pelvic rays 4 or 5 (usually 4); lateral line on ocular side of head with three branches; vertebrae 36-38; dorsal pterygiophores anterior to fourth neural spine 7-11; body slender, the depth 2.85-3.15 in SL; caudal peduncle absent or extremely short; head short, the length 4.7-5.15 in SL; eye diameter 4.8-5.5 in HL; interorbital width 9.55-10.7 in HL; longest dorsal ray 1.7-2.0 in HL; caudal fin 3.95-4.1 in SL; ocular-side pelvic fin anterior to blind-side fin; ocular-side pelvic fin joined by membrane to base of genital papilla, the fin of blind side joined to blind-side of anal papilla; pelvic fins reaching base of second anal ray, 2.3-2.6 in HL; no scales extending out on dorsal and anal rays; colour of ocular side in alcohol light grey- brown, with many small blackish spots, and three longitudinal rows of blackish blotches of about twice eye diameter; dorsal and anal fins pale with a dark middle streak on rays; caudal fin with small dark spots on rays. Largest specimen, $59.1 \mathrm{~mm}$ SL

\section{Description}

Dorsal rays 71 (65-72), anal rays 54 (50-56), most dorsal and anal rays branched (first 14 dorsal rays and first three anal rays of holotype unbranched); caudal rays 18, 12-14 branched, (14 in holotype), most of these double branched (12 in holotype); pelvic rays 4 ( 4 or 5; nine paratypes with 4 rays on both sides; six with 4 on ocular side, 5 on blind side; and one with 5 on both sides); no pelvic rays branched; lateral-line scales 76 (71-84), including 6 before a vertical at upper end of gill opening, then forming three branches, the upper ( 7 pores on holotype) angling dorsoanteriorly about $115^{\circ}$ to posterior lateral line, the middle branch ( 5 pores on holotype) continuing toward ventral part of upper eye, and the third branch ventrally (10 pores of this branch counted on holotype); scales above lateral line on ocular side about 23, including 3 on base of dorsal fin; scales below lateral line about 27, including 3 on base of anal fin; vertebrae $9+27(9+$ 28-29); 2 (2, rarely 3) dorsal pterygiophores, including erisma, before tip of second neural spine; space between second and third neural spines with 4 (3-6) pterygiophores; space between third and fourth neural spines with 3 (2-3) pterygiophores, hence a total of 9 (7-11) dorsal pterygiophores anterior to fourth neural spine. Ventroanterior margin of urohyal forming an angle of about $85^{\circ}$

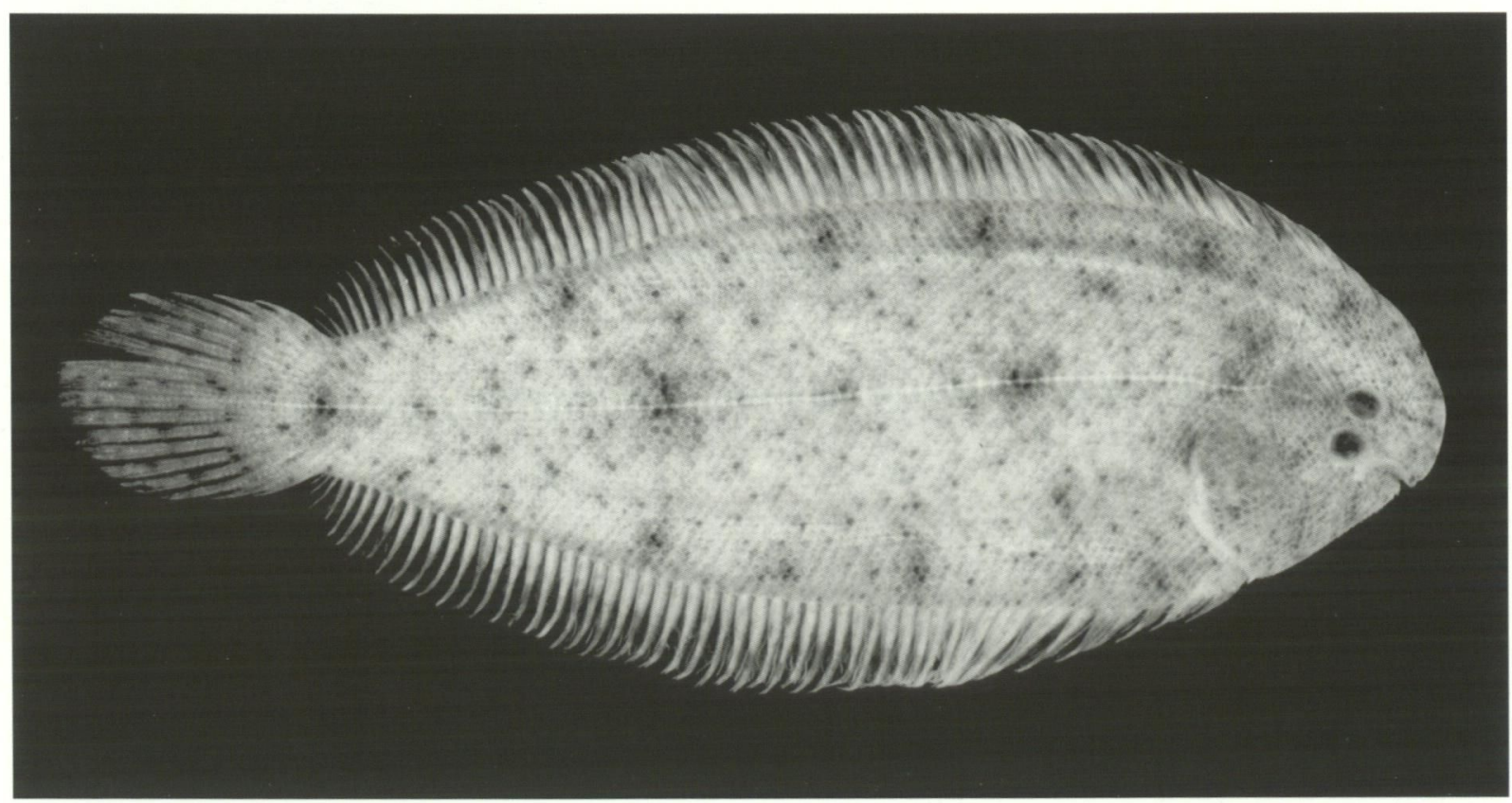

Figure 10 Holotype of Leptachirus triramus sp. nov., NTM S.11543-004, 39.6 mm SL, Victoria River, Northern Territory, Australia. 
$\left(75-85^{\circ}\right)$, the inner angle slightly to moderately rounded.

Body slender, the depth $3.0(2.85-3.15)$ in SL; body thin, the width (thickness) $3.95(3.75-4.75)$ in body depth; head short, the length $5.0(4.7-5.15)$ in SL; caudal peduncle depth 1.65 (1.55-1.8) in HL; caudal-peduncle length varying from nearly $0(0-$ 10) in HL; snout overhanging lower lip when mouth fully closed, the dorsal profile of snout abruptly ventroanterior to front of lower lip; snout length $2.6(2.5-2.8)$ in $\mathrm{HL}$; preorbital length 2.65 (2.65-2.7) in HL; eyes of moderate size, the eye diameter $4.8(4.9-5.95)$ in $H L$; least vertical interorbital width 9.55 (9.6-10.7) in HL; upper eye overlapping one-half (one-third to two-thirds) of lower eye; a horizontal line projected anteriorly from upper end of gill opening passing about onehalf eye diameter below lower eye.

Mouth inferior, the jaws strongly curved; maxilla reaching a vertical through anterior edge of pupil of lower eye, the upper-jaw length 2.8 (3.25-3.5) in HL; a band of villiform teeth on blind side of both jaws in about 4 rows at maximum width; tubular anterior nostril in front of upper half of lower eye, its length about equal to diameter of base and only slightly tapered; posterior nostril an oblique slit covered by thin skin anterior to base of lower half of eye; anterior nostril of blind side a short, strongly tapered tubule no longer than its base, above upper lip nearly one-half distance from front to end of upper jaw; posterior nostril of blind side posterior and slightly dorsal to anterior nostril, the internarial distance equal to eye diameter, the tubule similar in shape to anterior nostril but smaller, flattened, and directed posteriorly.

Scales ctenoid on both sides, those of ocular side with 6-10 prominent cteni; scales on ocular side of snout smaller, with fewer cteni, and none before anterior nostril; scales of blind side with 5-8 cteni; scales smaller and with fewer cteni on blind side of head, absent before anterior nostril; eyes separated by only one row of small scales, discounting those extending onto medial edges of eyes; no series of cirri along anterior edge of snout, though fine cirri on blind side nearly to edge; a series of about 35 fine cirri on blind side near edge of head between mouth and gill opening, the longest on chin about one-third eye diameter; a series of about 15 small cirri along opercular edge of gill opening of blind side, but none on ocular side.

Lateral line straight on both sides along middle of body, branching on head of ocular side as described in Diagnosis, the middle branch projecting toward dorsal edge of upper eye; lateral line extending with pores into caudal fin along dorsal edge of tenth ray three-fourths distance to posterior fin margin; cephalic sensory system of blind side as described for genus, with about 10 temporal commissures (sensory lines alternating with broad bands of cirri) linking dorsal cephalic

Table 12 Proportional measurements of type specimens of Leptachirus triramus as percentages of the standard length.

\begin{tabular}{|c|c|c|c|c|c|c|c|}
\hline & \multirow{2}{*}{$\begin{array}{c}\text { Holotype } \\
\text { NTM } \\
\text { S.11543 }\end{array}$} & \multicolumn{6}{|c|}{ Paratypes } \\
\hline & & $\begin{array}{c}\text { WAM } \\
\text { P.20608 }\end{array}$ & $\begin{array}{c}\text { BPBM } \\
40455\end{array}$ & $\begin{array}{c}\text { WAM } \\
\text { P.20608 }\end{array}$ & $\begin{array}{c}\text { WAM } \\
\text { P.20608 }\end{array}$ & $\begin{array}{c}\text { WAM } \\
\text { P.30067 }\end{array}$ & $\begin{array}{c}\text { WAM } \\
\text { P.20608 }\end{array}$ \\
\hline Standard length $(\mathrm{mm})$ & 39.6 & 42.3 & 45.3 & 47.2 & 47.5 & 51.7 & 59.1 \\
\hline Body depth & 33.1 & 33.2 & 32.7 & 31.6 & 31.7 & 32.3 & 35.1 \\
\hline Body width & 8.4 & 8.5 & 8.3 & 8.4 & 8.4 & 6.8 & 8.7 \\
\hline Head length & 20.1 & 21.3 & 19.4 & 20.1 & 20.0 & 20.3 & 20.3 \\
\hline Snout length & 7.8 & 7.6 & 7.0 & 8.1 & 7.4 & 7.8 & 7.2 \\
\hline Preorbital length & 7.6 & 7.8 & 7.2 & 7.4 & 7.4 & 7.5 & 7.6 \\
\hline Eye diameter & 4.2 & 3.6 & 3.9 & 4.1 & 4.0 & 3.9 & 3.4 \\
\hline Interorbital width & 2.1 & 2.0 & 1.8 & 2.1 & 2.1 & 2.0 & 1.9 \\
\hline Upper-jaw length & 7.1 & 6.4 & 5.5 & 6.2 & 6.2 & 5.8 & 5.9 \\
\hline Caudal-peduncle depth & 12.2 & 12.4 & 11.6 & 11.5 & 11.4 & 13.2 & 11.1 \\
\hline Caudal-peduncle length & 0.1 & 0.1 & 0 & 0.1 & 0.1 & 0.1 & 0.1 \\
\hline Predorsal length & 5.6 & 6.1 & 5.7 & 5.8 & 5.3 & 4.9 & 5.1 \\
\hline Preanal length & 20.8 & 21.1 & 20.0 & 21.0 & 20.8 & 20.9 & 20.2 \\
\hline Prepelvic length & 15.7 & 16.2 & 15.3 & 15.2 & 14.8 & 15.4 & 14.2 \\
\hline First dorsal ray & 6.8 & 7.1 & 6.6 & 6.8 & 6.2 & 6.4 & 6.6 \\
\hline Longest dorsal ray & 12.2 & 11.9 & 11.0 & 11.0 & 11.5 & 10.7 & 10.1 \\
\hline First anal ray & 5.6 & 6.8 & 5.5 & 6.1 & 5.8 & 6.1 & 5.1 \\
\hline Longest anal ray & 12.5 & 12.1 & 11.1 & 11.2 & 11.8 & 10.7 & 10.4 \\
\hline Caudal-fin length & 25.3 & 24.8 & 24.4 & 24.8 & 24.3 & 24.3 & 24.6 \\
\hline Pelvic-fin length & 7.8 & 9.4 & 8.4 & 8.3 & 8.5 & 8.2 & 8.3 \\
\hline
\end{tabular}

The full museum number for the holotype, is NTM 5.11543-004; for the paratypes, WAM P.20608-001 and WAM P.30067-007. 
branch of lateral line with cephalodorsal line along base of dorsal fin.

Basal sheath of three rows of small scales on dorsal and anal fins; base of caudal fin with seven rows of progressively smaller scales, then tiny scales, still with cteni, continuing out on rays; dorsal and anal rays on both sides with a membranous ridge extending more than half way to ray tips (less developed posteriorly) no scales extending onto rays, and no cirri on edges of ridges; anterior rays of dorsal fin without filamentous tips.

Origin of dorsal fin (base of first ray) anterior to ventral edge of upper eye, the predorsal length 3.6 (3.4 4.15) in HL; first dorsal ray $2.95(2.95-3.2)$ in $\mathrm{HL}$; longest dorsal ray 1.7 (1.75-2.0) in HL; origin of anal fin below base of eighteenth dorsal ray, the preanal length $4.8(4.75-5.0)$ in SL; first anal ray 3.6 (3.15-4.0) in HL; longest anal ray $1.6(1.75-1.95)$ in HL; anus anterior to first anal ray; caudal fin 3.95 (4.05-4.1) in SL; origin of ocular-side pelvic fin adjacent to second ray of blind-side fin; second pelvic ray longest, reaching base of second anal ray, 2.6 (2.3-2.5) in HL; genital papilla small, at dorsal edge of anus, and joined to last membrane of ocular-side pelvic fin; pelvic fin of blind side ending at ventral edge of anal papilla.

Colour of ocular side of holotype in alcohol light grey-brown mottled with many very small dusky blotches and dark brown spots of one-scale size; three longitudinal rows of larger dark blotches consisting of two to six dark brown scales within a dusky blotch: one row of six blotches below base of dorsal fin, one of five blotches above base of anal fin, and a row of six largest blotches along lateral line (with a few lesser spots between); lateral line nearly white; membranes of fins translucent; rays of dorsal, anal, and pelvic fins pale yellowish with a dark brown streak of variable length basally on membranous ridge, on some rays extending to three-fourths ray length; caudal fin with small dark spots on rays forming six indistinct curved transverse rows; colour of blind side pale yellowish without dark markings, except small dark spots of caudal fin of ocular side visible on blind side.

\section{Etymology}

This species is named triramus from the Latin tri for three and ramus for branch, in reference to the three branches of the lateral line on the ocular side of the head.

\section{Remarks}

This species was first collected from Wattie Creek, Victoria River, Northern Territory of Australia, and two localities in the Ord River, Western Australia conly about $100 \mathrm{~km}$ separate the mouths of the Victoria and Ord Rivers). All three localities are freshwater sites. In May 2007, Shane Hurley collected three live soles of this species from the
Daly River, Northern Territory at night in a moderately fast part of the river by placing a scoop net in the shallows on sand and disturbing soles upcurrent from the net. They were sent to Gordon Stables in Cairns and from him by Fenton Walsh to Jeffrey W. Johnson of the Queensland Museum. Having been a reviewer of this manuscript, Johnson recognized them as Leptachirus triramus and provided counts of dorsal rays, anal rays, and lateral-line scales. The specimens are now QM paratypes, and his counts were added to the present description and tables.

Two lots from the West Baines River, Northern Territory, NTM S.14132-002, 18: 32.0-41.2 mm (15'41'S, 129 54'E) and NTM S.14134-005, 13: 33.8$50.8 \mathrm{~mm}\left(15^{\circ} 57^{\prime} \mathrm{S}, 129^{\circ} 44^{\prime} \mathrm{E}\right)$, both freshwater localities with tidal effect during extremely high tides, are provisionally identified as Leptachirus triramus and not designated as paratypes. Counts of dorsal rays, anal rays, and lateral-line scales were made on the 20 largest specimens of both lots. The dorsal and anal fin-ray counts are within the range for typical L. triramus, but the lateral-line scale counts are distinctly lower, ranging from 70-76, compared to 71-84 for typical L. triramus. Vertebral counts were taken from $x$-rays of the 13 specimens of NTM S.14134-005. The counts ranged from 3739 , with a strong mode at 38 ; therefore an average of one more vertebrae than the remaining specimens. This was unexpected because the West Baines River drains to the Victoria River. Additional collections within the Victoria River system should be made and genetic study of the populations initiated.

Leptachirus triramus is easily distinguished from all other species of the genus by having three instead of two branches of the lateral line on the ocular side of the head, the ocular-side pelvic fin attached to the base of the genital papilla, larger eyes, lower average vertebral count, and no scales extending out on the dorsal and anal rays. These characters might suggest the classification of this species in a distinct genus. However, there is even more variation of major characters within the 47 species of the similar genus Aseraggodes.

Three branches of the lateral line on the ocular side of the head, and the attachment of a pelvic fin to the base of the genital papilla are also found in Aseraggodes normani. However, the dorsal branch of the lateral line on the head of $A$. normani is not directly above the ventral preopercular branch, as in L. triramus, and its pelvic fins are both attached by common membrane to the genital papilla. Other characters of normani, such as its much deeper body (2.3-2.55 in SL), weakly ctenoid scales, fully scaled snout, cirri on the dorsal and anal rays, and much larger size, readily provide complete generic separation. 


\section{ACKNOWLEDGEMENTS}

I thank Gavin Dally and Rex Williams of the Museums and Art Galleries of the Northern Territory, Shirleen Smith and Jeffrey T. Williams of the U.S. National Museum of Natural History, and Susan M. Morrison, Gerald R. Allen, and Connie Allen of the Western Australian Museum for the loan of specimens. I am grateful also to Gerald R. Allen, Gavin Dally and Helen K. Larson for information on the habitat of type specimens, Jeffrey W. Johnson for data on the three Queensland Museum paratypes of Leptachirus triramus, James Maclaine of the Natural History Museum, London for X-rays, and Loreen R. O'Hara and Arnold Y. Suzumoto of the Bishop Museum for X-rays and curatorial assistance. The manuscript was reviewed by Martin F. Gomon, J. Barry Hutchins, and Jeffrey W. Johnson, all of whom made valuable suggestions for improvement.

\section{REFERENCES}

Carpenter, K.E. and Niem, V.H. (eds.) (2001). The Living Marine Resources of the Western Central Pacific. Vol. 6. Bony fishes part 4 (Labridae to Latimeriidae...marine mammals). Rome: Food and Agriculture Organization of the United Nations. v + 3381-4218.

Clark, E. and George, A. (1979). Toxic soles, Pardachirus marmoratus from the Red Sea and $P$. pavoninus from Japan, with notes on other species. Environmental Biology of Fishes 4(2): 103-123.

Erftemeijer, P., Allen, G. and Zuwendra. (1989). Preliminary resource inventory of Bintuni Bay and recommendations for conservation and management. Asian Wetlands Bureau Report (Gobor, Indonesia): 1151.

Eschmeyer, W.N. (1998). Catalog of Fishes. San Francisco: California Academy of Sciences. 3 volumes: 1-2905.

Günther, A. (1862). Catalogue of the fishes in the British Museum. British Museum, London, xxi +534 pp.

Ochiai, A. (1963). Fauna Japonica Soleina (Pisces). Tokyo: Biogeographical Society of Japan, vi $+114 \mathrm{pp}$.

Randall, J.E. (1996). Two new soles of the genus Aseraggodes (Pleronectiformes: Soleidae) from the Hawaiian Islands. Pacific Science 50(4): 427-440.

Randall, J.E. (2002). Aseraggodes holcomi, a new sole (Pleuronectiformes: Soleidae) from the Hawaiian Islands. Pacific Science 56(3): 247-253.

Randall, J.E. (2005). A review of the soles of the genus Aseraggodes from the South Pacific, with descriptions of seven new species and a diagnosis of the genus Synclidopus. Memoirs of Museum Victoria 62(2): 191212.
Randall, J.E. and Bartsch, P. (2005). Two new soleid fishes of the genus Aseraggodes from Micronesia, with a record of A. smithi from Palau. Micronesica 38(2): 125-139.

Randall, J.E. and Bartsch, P. (In press). Aseraggodes corymbus, a new soleid fish from the Gulf of Carpentaria, Australia. Mitteilungen aus dem Museum für Naturkunde in Berlin - Zoologische Reihe.

Randall, J.E. and Desoutter, M. (In press). Review of the soles of the genus Aseraggodes (Pleuronectiformes: Soleidae) from the Indo-Malayan region, with descriptions of nine new species. Cybium.

Randall, J.E. and Gon, O. (2005). Review of the soles of the genus Aseraggodes of the western Indian Ocean, with descriptions of three new species. Israel Journal of Zoology 51: 165-190.

Randall, J.E. and Johnson, J. W. (2007). Revision of the Indo-Pacific soleid fish genus Pardachirus. IndoPacific Fishes, no. 39: 1-22.

Randall, J.E. and Meléndez, R. C. (1987). A new sole of the genus Aseraggodes from Easter Island and Lord Howe Island, with comments on the validity of $A$. ramsaii. Bishop Museum Occasional Papers 27: 97105.

Randall, J.E. and Senou, H. (2007). Two new soles of the genus Aseraggodes (Pleuronectiformes: Soleidae) from Taiwan and Japan. Zoological Studies 46(3): 303-310.

Roberts, T.R. (1978). An ichthyological survey of the Fly River in Papua New Guinea with descriptions of new species. Smithsonian Contributions to Zoology, no. 281: vi +72 pp.

Saruwatari, T, Lopez, J.A. and Pietsch, T.W. (1997). Cyanine blue: a versatile and harmless stain for specimen observation. Copeia 1997(4): 840-841.

Weber, M. (1907). Süsswasserfische von Neu-Guinea ein Beitrag zur Frage nach dem früheren Zusammenhang von Neu-Guinea und Australien. In: Nova Guinea. Résultats de l'expédition scientifique Néerlandaise à la Nouvelle-Guinée. Süsswasserfische Neu-Guinea, vol. 5 (Zool.) pt. 2: 201-267.

Weber, M. (1913). Süsswasserfische aus Niederländisch Süd- und Nord-Neu-Guinea. In: Nova Guinea. Résultats de l'expédition scientifique Néerlandaise à la Nouvelle-Guinée. Zoologie. Leiden. Zool. Nouvelle-Guinée, vol. 9 (livr. 4): 513-613.

Manuscript accepted 25 June 2007 